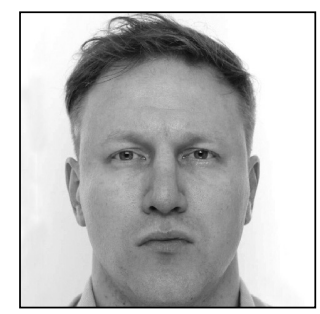

Erkki Hirsnik

Dr. iur., Judge

Tartu County Court

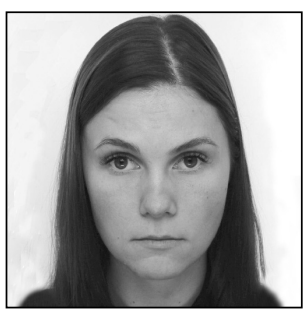

Marje Allikmets

Adviser to the Criminal Chamber Supreme Court of Estonia

\title{
Restraining at Care Institutions, Evaluated from the Standpoint of Penal Law
}

\section{Introduction}

The title of this article needs some explanation. Although the focus of the article is on providing an assessment of restraining that takes place both in health-care institutions and in social-welfare institutions, we will use a term that encompasses both of these, 'care institutions', to simplify reading. Although several positions expressed in this article may be applicable to other fields also (e.g., in provision of health-care services in accordance with Chapter 41 of Estonia's Law of Obligations Act $\left.{ }^{* 1}\right)$, the article uses the general term 'care institutions' to refer to general care homes (retirement homes in the meaning of $\$ 20$ of the Social Welfare Act ${ }^{*_{2}}$, or SWA), special care homes (see the SWA's §100), psychiatric hospitals providing inpatient psychiatric care under the Mental Health Act ${ }^{*}$ (MHA), and nursing hospitals providing inpatient nursing services (as addressed in $\S 24$ of the Health Services Organisation Act and elsewhere ${ }^{*} 4$ ). The main elements connecting these institutions are that they usually accommodate relatively helpless people and, secondly, there may often be a need to perform acts described in some of the provisions of the special part of the Penal Code directed at these people.

The article also repeatedly uses the word 'caretakers'. This refers to all employees at care institutions: doctors, nurses, caregivers, and activity instructors. 'Care patients', in turn, are the people who receive any kind of service at care institutions as defined above.

Finally, restraining (or implementing forms of restraint) within the meaning of this article is carrying out acts that comprise elements necessary for a criminal offence towards care patients, where those acts are performed by caretakers so as to eliminate or reduce a threat to legal rights that arises from said care patients. First of all, this definition means that the article does not address those means of restraint that feature no legally defining elements of a criminal offence. For instance, it does not address whether a certain means of restraint could bring about any consequences in disciplinary proceedings or an obligation to compensate for the damages incurred, nor does it address the instances in which a caretaker's acts entail the necessary elements for a criminal offence under other consideration than minimising threat - for instance,

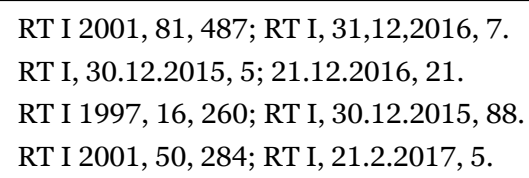


illegal appropriation of jewellery of a care patient (see $\S 199$ of the Penal Code ${ }^{*}$ (PC), on larceny) or torture of a care patient for sadistic reasons (see the PC's \$121, on physical abuse). Neither is medical treatment of the person in care a topic of the discussion here. ${ }^{* 6}$ Lastly, acts of people who are not caretakers are not considered, with examples being the care patients themselves and visitors to the institutions (although largely the same considerations apply to the punishments for such actions as to the liability of caretakers).

Since there is very little legal literature (and case law) on this matter, the analysis in the article is based in large part on German law as an important model for Estonian law.

\section{Restraint in connection with the elements necessary for a criminal offence}

The connection of means of restraint to the necessary elements of a criminal offence can be two-sided. Firstly, the measures of restraint may correspond to a description established in some of the provisions of the Penal Code. This means that a restrainer may be criminally liable for restraining. Secondly, it should be noted that sometimes criminal liability can follow when caretakers do not resort to restraining measures: they could be held responsible for offence through omission. Therefore, a caretaker's job is full of responsibilities and dangerous in the sense of criminal law: a punishment can follow from either act or omission. In Germany, caretakers share a grim joke that they always have one foot in a prison. ${ }^{*}$

In cases of implementation of means of restraint, several sets of conditions in the special part of the Penal Code may apply. The main provision to be examined in this connection, however, is found in $\S 136$ of the PC (on unlawful deprivation of liberty). That is why the article addresses this provision thoroughly before proceeding to analysis of some other provisions of the special part of the Penal Code that may become relevant.

\subsection{Deprivation of liberty}

Subsection 136 (1) of the PC stipulates pecuniary punishment or up to five years' imprisonment for unlawful deprivation of the liberty of another person. Freedom in this context means freedom of movement. Section 136 of the PC is a delict with arbitrary description; i.e., any kind of action can be considered to have the constituent elements of an offence if it results in rendering it impossible for the victim to change location. ${ }^{*} 8$

Among classic examples of deprivation of liberty are tying a person up and locking someone in a room. Hence, for instance, deprivation of liberty within the meaning of $\S 136$ of the PC can be considered in the context of this topic if a patient is being forcibly restrained within the sense of \$14 (2) 1) of the MHA, is strapped to a bed within the meaning of \$14 (2) 3) of the MHA, or is placed in an isolation room in the meaning of $\S 14$ (2) 4) of the MHA or $\$ 107$ of the SWA. In contrast, there are no grounds for discussing deprivation of liberty in a case wherein the person is not locked inside a room but one or more particular rooms are closed to that person, for instance, to prevent the patient from accessing other patients, his or her possessions, or the television set. Such infringement of freedom of movement in relation to a specific matter does

RT I 2001, 61, 364; RT I, 31,12,2016, 14.

6 However, it should be noted here that it is questionable whether treating a person even is consistent with the necessary elements of a criminal offence. For instance, German case law and some legal literature find that also influencing bodily functions for the purpose of treatment (e.g., a scalpel incision or a syringe prick) should be deemed damage to health (the unlawfulness of which can be precluded through patient consent); see the overview given by T. Fischer. Strafgesetzbuch. Kommentar. 63 . Aufl. ['Penal Code: 63rd, Commented Edition']. Munich, Germany, 2016 (in German), Art. 223, references 16-20. However, a large part of German legal literature has expressed an opposite view and indicated that steps taken to improve a person's health cannot be deemed causing of health damage. Estonian legal literature shares this opinion; see A. Nõmper, J. Sootak. Meditsiiniõigus ['Medical Law']. Tallinn 2007 (in Estonian), pp. 122-123.

7 F. Henke. Fixierungen in der Pflege. Rechtliche Aspekte und praktische Umsetzung. 1. Aufl. ['Restraints in Care: Legal Aspects and Practical Implementation']. Stuttgart, Germany, 2006 (in German), p. 5.

8 J. Sootak, P. Pikamäe. Karistusseadustik. Kommenteeritud väljaanne ['Penal Code: Commented Edition']. 4th, updated and revised ed. Tallinn: Juura 2015 (in Estonian), §136, Comment 3.2.1 (M. Kurm); T. Fischer (see Note 6), §239, Comment 6; W. Joecks. Strafgesetzbuch. Studienkommentar. 10. Aufl. ['Penal Code: 10th, Commented Study Edition']. Munich, Germany, 2012 (in German), Art. 239, Comment 8. 
not deprive the person of freedom of movement to any location apart from the one(s) at issue ${ }^{*} 9-$ e.g., other rooms at the care institution, outdoors, or the whole wide world.

At the same time, there are other ways of depriving someone of liberty.

One of these is by means of threatening, but not just any threatening. In light of the ultima ratio principle of penal law, only those threats exceeding a certain level of intensity may be considered. When a person places a gun at another person's temple and forbids that other person to move, this may constitute deprivation of liberty in the meaning of $\$ 136$ of the PC. ${ }^{* 10}$ Namely, the person holding the gun implies(concludently) to the person held at gunpoint that, in the event of any movements, the victim will be killed. Threatening someone's life is undoubtedly of sufficient intensity to imbue an act with the necessary elements of a criminal offence under $\S 136$ of the PC, as life is the most important legal right under penal law. Generally, in cases of the necessary elements articulated in $\S 136$, the main aspects addressed could be threats within the meaning of $\$ 120$ of the PC - i.e., threatening to kill, cause harm to health, or cause significant damage to or destroy property. But there may be other potential sufficiency provisions among them: for a threat to cause pain (the second of the three options in \$121 (1) of the PC); in the context of sexual offences, forcing a person who is not capable of comprehending the situation (see \$141 (1) of the PC) to remain still by a threat that if the victim attempts to leave, the person doing the threatening will engage in sexual intercourse with the victim; and implying that if trying to leave, the person threatened will be locked in a cage (see $\$ 136$ of the PC, with regard to depriving another person of liberty by threatening to deprive that person of liberty). Also, it has been found in Germany that the anticipated threat must be direct - referring to some action far in the future is not sufficient. ${ }^{* 11}$

In the context of a care institution, the above-mentioned understanding means the following. If the caretaker tells a confused care patient trying to leave the territory of the institution that if the patient does not immediately give up on what he or she is doing and return to the building, the caretaker will be forced to lock the patient up in a room, this constitutes deprivation of liberty within the meaning of $\$ 136$ of the PC - the caretaker has threatened to interfere with a rather significant legal right protected by penal law. However, if the caretaker states that in a case of attempted escape, he or she is forced to take action, there is no deprivation of liberty involved. Firstly, this is because the caretaker does not imply directly or concludently that a new escape attempt would bring about intervention in respect of a (significant) legal right protected by penal law: taking action could mean anything - contacting the patient's relatives, discussing the matter with other doctors, etc. Secondly, because the action referred to would take place in an unspecified future according to the caretaker, sufficient grounds for identifying an offence do not exist. Also, there is no deprivation of liberty within the meaning of $\S 136$ of the PC when, for instance, a caretaker who has caught a care patient trying to leave the institution says that if the patient fails to voluntarily and immediately return to the building, the patient will get no dessert (knowing that the person in question is a sweet tooth). The latter is threatening merely with unpleasant consequences and is not significant from the standpoint of penal law.

Deprivation of liberty can come about also by administering certain substances, such as medicinal ones, to a person. When a person is unable to move on account of the medication (e.g., falling asleep because of sleeping pills or losing consciousness through effects of anaesthetic), that person has been deprived of liberty within the meaning of $\S 136$ of the PC. With regard to the means, such deprivation of liberty may take place within the meaning of the second alternative of §21 (1) of the PC. This is the case when a caretaker administers a medication restricting the movements of the care patient while the patient is unaware of such effect of the medication when consuming (e.g., swallowing) it (e.g., the caretaker has not explained it) or when the fact of administering the medication is altogether hidden from the care patient (e.g., it is concealed in food). ${ }^{*}$ In such cases, care patients directly deprive themselves of freedom on their own; however, the caretaker controls the action of the care patient (who is the means in the sense of execution), thereby bringing

9 G. Arzt et al. Strafrecht. Besonderer Teil. 2. Aufl. ['Criminal Law: Special Part, Second Edition']. Bielefeld, Germany (in German), Art. 9. Ref. 17; M. Heghmanns. Strafrecht für alle Semester. Besonderer Teil ['Criminal Law for All Academic Terms: Special Part']. Heidelberg, Germany, 2009 (in German), Ref. 663.

10 J. Sootak, P. Pikamäe (see Note 8), §136, Comment 3.2.2 (M. Kurm).

11 K. Lackner et al. (eds). Strafgesetzbuch. Kommentar. 28. Aufl. ['Penal Code: 28th, Commented Edition']. Munich, Germany, 2014 (in German), Art. 239, Comment 2 (K. Kühl); A. Schönke, H. Schröder (eds). Strafgesetzbuch. Kommentar. 29. Aufl. ['Penal Code: 29th, Commented Edition']. Munich, Germany, 2014 (in German), Art. 239, Comment 6 (A. Eser, J. Eisele).

12 For example, the Chancellor of Justice has referred to the fact that in a certain care institution, the care patients were secretly given sedatives in their evening tea. See the summary of the Chancellor of Justice's 1.10.2014 inspection visit, titled 'Kontrollkäik AS Hoolekandeteenused Erastvere Kodusse' (or 'Visit to the Erastvere Home, of AS Hoolekandeteenused'), p. 7 
about the necessary elements for an offence under $\$ 136$ of the PC, with predominant knowledge: the person giving the medicine is unlike the means (the care patient) in being aware of its mobility-restricting effect. When, in contrast, the person taking the medication does so knowingly and understands its effect, there are no grounds for claiming deprivation of liberty within the meaning of $\$ 136$ of the PC. Since the act of deprivation of liberty is committed by the care patients themselves (they voluntarily swallow the medicine), direct performance of the act by the caretaker in the meaning of the first option in §21 (1) of the PC cannot be considered relevant. At the same time, instrumental execution is ruled out by the fact that the caretaker has no control over the action - there is no predominant knowledge, because the care patient is aware of the effects of the medication. There is, however, a possibility of considering the caretaker's control of the action (i.e., instrumental execution) when the care patient does not comprehend the effects of the medication (e.g., for reason of a mental disorder): in such a case, the caretaker controls the means (the care patient) through no fault of the latter. ${ }^{*}{ }^{13}$ On the other hand, in a situation in which the care patient receives medication via a perfusor (syringe pump), the caretaker switching on the perfusor and/or adding the medication to it is directly depriving the care patient of liberty: mobility restriction occurs with the action of the caretaker (switching on the perfusor and/or adding medication to it) directly, without intervention by someone else (whether the care patient or a third person). The same is true of injecting the medication. Deprivation of liberty is direct also when the caretakers force a care patient to swallow the medication - for instance, two people might hold the person still while a third one opens the patient's mouth and a fourth forces the pill down the patient's throat. In such a case, the swallowing reflex of the care patient cannot be considered an action - if it could be, we could talk about instrumental execution - in a penal-law sense because the care patient was unable to command that movement (i.e., swallowing) by will.

It is debatable whether deprivation of liberty presumes that the victim was able to change location at the moment of deprivation of liberty (e.g., one is unable to do so while unconscious or asleep) or is aware of losing liberty (as when a teacher marking exam papers in the teachers' lounge does not notice that some naughty students locked the door of the lounge, left it locked for a while, and later unlocked it). In Germany, both positions are represented: that deprivation of liberty presumes the victim's awareness of losing liberty and the opposite. ${ }^{*} 4$ Those who support the latter contention find deprivation of liberty to encompass cases in which freedom of movement is taken from an unconscious person - the person may regain consciousness and wish to move. The same argument applies to people who are unaware of being deprived of their liberty. For instance, the teacher in the parenthetical example above may develop a need to visit the toilet. Even if the first position (i.e., that there can be no deprivation of liberty if the person is unaware of it) is supported, it does not follow that such cases cannot bring liability under penal law. If the person depriving someone else of liberty at least accepts within the sense of \$16 (4) of the PC that the person deprived of liberty might want to exercise his or her freedom of movement, there are grounds for viewing the action as attempted deprivation of liberty within the meaning of $\S \S 136$ (1) and 25 (2) of the PC. An example case would arise when a caretaker installs a grate on a care patient's bed that prevents him or her from leaving at night because the caretaker considers it possible and accepts that the patient may wake up and go wandering; another is a situation wherein a caretaker locks the door of the care patient's room for the night so that the patient could not start roaming around the hallways in the event of waking during the night.

It is generally agreed that a person's liberty can be taken away also by misleading that person - for example, by lying to the person with the statement that he or she is unable to leave the flat because the door is locked or by falsely claiming to the person that he or she cannot leave the vehicle because opening the door would cause a bomb placed in the car to detonate. ${ }^{*}{ }^{*}$ Therefore, deprivation of liberty within the

and Annex 1 (photo 1). Available, in Estonian, at http://www.oiguskantsler.ee/sites/default/files/field_document2/kontrollkaigu_kokkuvote_as_hoolekandeteenused_erastvere_kodu_0.pdf (in Estonian) (most recently accessed on 26.5.2017).

13 See, for example, R. Rengier. Strafrecht. Allgemeiner Teil. 4. Aufl. ['Criminal Law: General Part, 4th Ed.']. Munich, Germany, 2012 (in German), Art. 43, refs 27-37.

14 See, for example, G. Arzt et al. (see Note 9), Art. 9, refs 13-16; T. Fischer (see Note 6), Art. 239, Comment 5; W. Joecks (see Note 8), Art. 239, Comment 10 ff.; M. Heghmanns (see Note 9), Ch. 19, Ref. 657.

15 T. Fischer (see Note 6), Art. 239, Comment 8; W. Joecks (see Note 8), Art. 239, Comment 17; G. Arzt et al. (see Note 9), Art. 9 , Ref. 26; M. Heghmanns (see Note 9), Ch. 19, refs 661 and 665; W. Joecks, K. Miebach (eds). Strafgesetzbuch. Münchener Kommentar ['Munich Commentary on the Penal Code'], Vol. 4. 2nd ed. (volume editor: G.M. Sander). Munich, Germany, 2012 (in German), Art. 239, Comment 27 (B. Wieck-Noodt); A. Schönke, H. Schröder (see Note 11), Art. 239, Comment 6; K. Lackner et al. (see Note 11), Art. 239, Comment 2. It has also been found in Estonian legal literature that deprivation of liberty by deceit is possible; see J. Sootak, P. Pikamäe (see Note 8), §136, Comment 3.2.2 (M. Kurm). A decision of the 
meaning of $\S 136$ of the PC also covers a caretaker lying to a care patient in a manner plausible to the latter that the front door of the care institution is locked or electrified or that there are aggressive dogs in the yard outside. Deprivation of liberty might also consist in, for instance, having 'tricky' door handles that need to be pulled up instead of pushed down to open. ${ }^{*} 16$

The conditions for deprivation of liberty do not necessarily presume that the obstacle on the way to freedom is absolutely insurmountable (e.g., strong bonds or a windowless concrete cage with a heavy locked iron door). If access to freedom is in some way possible, the existence of the elements of deprivation of liberty depends on the particulars of the circumstances. For instance, the opinion has been expressed in Germany that if the possibility of using an emergency exit can be presumed, there can be no deprivation of liberty. ${ }^{*}{ }^{17}$ First and foremost, the person inside cannot make well-grounded assumptions as to whether using it is dangerous. ${ }^{*} 8$ For instance, it is generally not dangerous to leave through an evacuation door instead of the locked main door. The same can be said about exiting via a low window. ${ }^{* 19}$ It has been generally found that a person walking around nude can be presumed as a response, with regard to the question of whether taking the clothes of a person who has gone for a swim constitutes deprivation of that person's liberty. ${ }^{*}{ }^{20}$ However, deprivation of liberty should be affirmed as occurring when the escape attempt would entail jumping from a high window or moving car or if opening the exit itself could cause bodily injury. ${ }^{{ }_{21}}$ Similarly, it could be said that, while taking the care patient's clothes does not constitute deprivation of liberty - after all, the person could leave the institution either clothed or while naked - the situation might be completely different in a harsh winter when going outside without (proper) clothing on could lead to serious physical harm or even death. Finally, a serious obstacle to freedom of movement (i.e., deprivation of liberty) has been deemed not to exist when that physical obstacle could be removed by pressing a button for instance, when a care patient locked in a room or lying in a bed with raised rails can call for a caretaker by pressing a button, who will then arrive almost immediately and remove the obstacle. However, if the call is not responded to, deprivation of liberty can obviously be affirmed as present. ${ }^{* 2}$

Whether an action can be viewed as deprivation of liberty may depend greatly also on the person in question. For example, raising bed rails does not constitute deprivation of liberty for a person who is physically and mentally healthy, but it does for an ailing care patient who is unable to independently climb over or past the railing to get out of bed. When someone needs a wheelchair to move about, taking that wheelchair from him or her constitutes deprivation of liberty. ${ }^{* 23}$ In contrast, when a person in a wheelchair is unable to leave the chair on his or her own, strapping him or her into the wheelchair (e.g., to avoid falling) is not deprivation of liberty ${ }^{*}$, because moving by leaving the wheelchair is impossible for the person in any case and strapping in cannot increase the impossibility.

In the context of this article, it is important to note that liberty can be taken further from a person who is already deprived of it; that is, the person's mobility options can be additionally restricted. ${ }^{* 25}$ For instance, a person held in a building with several rooms (i.e., a person already deprived of liberty) can be additionally deprived of it by being locked in a single room or being tied up. Accordingly, an order by a court or doctor under $\S 105$ (4) of the SWA or §11 (2) or §11 (3) of the MHA for placement of a person in a closed institution

Supreme Court that does not seem relevant with regard to the matter is referred to (ibid.): the Supreme Court analysed a situation in which, although a person was lured into a car by deceit, no tricks were used to keep that person there.

16 C.W. Schmidt. Freiheitsberaubung aus Fürsorge ['False Imprisonment from Care']. Giessen, Germany 2010 (in German), p. 110. Available at http://geb.uni-giessen.de/geb/volltexte/2011/8036/pdf/SchmidtChristian_2011_02_16.pdf (most recently accessed on 27.5.2017).

17 W. Joecks, K. Miebach (see Note 15), Art. 239, Comment 28.

18 A. Schönke, H. Schröder (see Note 11), Art. 239, Comment 6a.

19 W. Joecks, K. Miebach (see Note 15), Art. 239, Comment 29.

20 Ibid.; A. Schönke, H. Schröder (see Note 11), Art. 239, Comment 6a; G. Arzt et al. (see Note 9), Art. 9, sidenotes 21-22.

21 W. Joecks, K. Miebach (see Note 15), Art. 239, Comment 30.

22 There have been such cases in Estonian care institutions. See the 11.3.2015 circular letter of the Chancellor of Justice to providers of nursing care services, para. 6 on p. 4. Available, in Estonian, at http://www.oiguskantsler.ee/sites/default/files/ field_document2/6iguskantsleri_soovitus_pohioiguste_ja_-_vabaduste_paremaks_tagamiseks_tahelepanekud_statsionaarse_oendusabiteenuse_osutajatele.pdf (most recently accessed on 25.5.2017).

23 C.W. Schmidt (see Note 16), p. 37.

24 C. Fuchs. Die Zulässigkeit von Patientenfixierungen ['The admissibility of restraints on patients'], p. 5. Available at http:// www.aerztenetz-bad-berleburg.de/images/zulaessigkeit_von_patientenfixierungen.pdf(in German) (most recently accessed on 27.5.2017).

25 G. Arzt et al. (see Note 9), Art. 9, Ref. 18. 
or involuntary psychiatric care may legitimise only keeping that person in the respective institution (i.e., in the building or in the relevant territory), while any additional restrictions to freedom of movement require separate justification. The above conclusion is clearly confirmed also by the existence of $\S \S 106$ and 107 of the SWA and $\S 14$ of the MHA: if a detention decision of a court or a doctor permitted every kind of restriction to freedom of movement, such provisions would not be necessary. ${ }^{{ }_{2} 6}$

\subsection{Other compositions of the special part of the Penal Code}

In cases of restraint, addressed in $\S 121$ of the PC, 'physical abuse' is often possible also. In the course of restricting a person's mobility, that person's body may be affected in a way that comprises the necessary elements presented in $\$ 121$ of the Penal Code. Even if it may not be, persons restricting liberty without corresponding training and suitable means may consider this outcome possible and acceptable, thereby fulfilling the necessary elements for attempted physical abuse within the meaning of §121 and §25 (2) of the Penal Code.

Section 121 of the PC specifies two alternatives in its terms: firstly, causing of damage to the health of another person and, secondly, physical abuse that causes pain. Health damage may consist of any kind of pathological condition ${ }^{* 27}$ - for instance, a fracture, bleeding, bruising, or influenza (caused by, for instance, being pushed into cold water). Since the legislation does not specify the manner of causing the health damage, this is a composition with unspecified description of action; that is, causing health damage in any way constitutes the offence. For instance, the action might be a punch or a kick, stabbing with a knife, throwing something at the person, or pushing the person down from somewhere. At the same time, health damage could come about from inserting a syringe needle into a person's body - it causes a wound. If a substance is administered to a person (e.g., orally in the form of pills or by injection), affecting his or her bodily functions - e.g., causing drowsiness (as with sleeping pills) or loss of consciousness (as with anaesthesia) - it is considered to cause a pathological condition (i.e., health damage).

Pain is an unpleasant sensory or perceived sensation occurring with actual or potential damage to tissue. ${ }^{* 28}$ However, in recent years, the case law of the Supreme Court of Estonia has started to incline in the direction that causing pain does not itself possess the necessary elements in $\S 121$ of the PC. Namely, a sensation of pain may arise very easily, so the Court has taken the position that not just any abuse that causes pain possesses the elements necessary for the offence. For instance, a requirement has been specified of the pain being a typical consequence of a certain action ${ }^{* 29}$; it has been found also that a certain degree of pain caused in penal intervention does not cross the line, since to some extent it is socially acceptable. ${ }^{*}{ }^{30}$ In this, Estonia has followed the same direction as Germany - to be considered physical abuse in the event of no health damage, the infringement of physical integrity must exceed some sort of social acceptability threshold. ${ }^{*}{ }^{11}$ Said interpretation is supported by the wording of the legislation: it is not causing pain per se that is deemed punishable but physical abuse that causes pain. In interpretation of the provision, emphasis should be put on the word 'abuse': it enables normatively furnishing the second alternative found in §121 (1) of the PC. Thus, it could be found that, for instance, stepping on someone's toe on a crowded bus with indirect intent and causing pain or lightly smacking a child for didactic purposes (causing some pain to the child) when done by a parent of the child does not objectively match the elements specified in §121 (1) of the PC.

Interpreting the second alternative in $\$ 121$ (1) of the PC in the way described above, one can conclude that caretakers causing pain to care patients in some of their actions or at least accepting the possibility of

26 True, it was later concluded that these grounds are largely unnecessary in the meaning of penal law (see Subsection 3.5 of this article), yet in the case of their absence, it would not be possible to state that additional deprivation of liberty would be possible on the grounds of a detention decision alone. In the absence of $\S \S 106$ and 107 of the SWA and $\S 14$ of the MHA, the reasoning should proceed from the nature of the deprivation: imposing an additional movement restriction limits the person's ability to change location or move the body, and that is the deciding factor.

27 J. Sootak, P. Pikamäe (see Note 8), §121, Comment 3.1 (M. Kurm); M. Heghmanns (see Note 9), Ch. 9, Ref. 376.

28 CCSCd 3-1-1-60-10, para. 16.

29 CCSCd 3-1-1-50-13, para. 12.

30 CCSCd 3-1-1-76-16, para. 12.

31 It is easier to do that in Germany, since the corresponding provision in German legislation (Section 223 of the German Penal Code, or (Strafgesetzbuch) does not mention pain - the position is that causing pain in itself does not constitute physical abuse; see M. Heghmanns (see Note 9), Ch. 9, Ref. 375. 
causing them pain does not satisfy the objective elements of an offence. For example, the quality of physical abuse might not exist in a situation in which caretakers take down a patient who presents an acute danger to his or her health or that of others so as to mitigate that danger while accepting that the care patient struggling in their arms may feel a certain amount of pain.

However, provisions related to threat or even damage to life (i.e., causing death) may be relevant in addition.

Let us begin by considering the PC's $\S \S 123$ (on placing in danger) and 124 (on refusal to provide assistance). These provisions could be relevant when someone's life is at risk, and §123 may apply also when there is serious risk to health. Among classic cases of life-threatening situations is lying unconscious on a road or outside in the cold during winter. In the case of a care institution, a life-threatening situation could exist also when a person tied to a bed is kept in the same room as people with mental disorders who move about freely. For instance, such a situation ended a couple of years ago with the death of the person lying in bed, suffocated by a mentally ill fellow patient. ${ }^{*}{ }^{2}$ Another instance that could be considered here is that in which a care patient with suicidal tendencies and incapable of relevant comprehension (see Subsection 3.1, below, on incapacity to comprehend) is left alone in a room where he or she could commit suicide. ${ }^{*} 33$ It is clear that not all situations involving a theoretical risk of death could be considered life-threatening - the threat must be specific. As for when the threat is sufficiently specific, that must be assessed by taking all the circumstances into consideration (which people are left in the room with the person being restrained, how often the person left alone has made suicide attempts, and when the last time was). It is important to note that $\S \S 123$ and 124 of the PC are action delicts and do not presume arrival of a consequence (death or, in the case of §123, 'only' damage to health) - it is sufficient for a situation fulfilling these conditions to exist (e.g., threat to life). While for $\$ 123$ of the PC the offender's acceptance of the danger is sufficient for holding the offender liable under $\$ 15$ (1) and 16 (4), §124 requires being fully aware of the life-threatening situation (its use of 'knowing' is important).

Sections 123 and 124 of the PC as delicts for everyone are applicable only when they do not get absorbed by a provision of higher relevance. First and foremost among these would be manslaughter by omission within the meaning of $\$ 113$ (1) and 13 (1) of the PC. ${ }^{*} 34$ Admittedly, manslaughter by action could be considered too, but in this case it is even less likely than manslaughter by omission.

A person can be held liable for manslaughter by omission only when under an obligation to prevent death - that is, when legally obliged to act within the meaning of $\$ 13$ (1) of the PC (i.e., when a guarantor). A caretaker has a (protection) guarantor obligation ${ }^{*} 35$ only when actually being the person providing the care. This means that the person in question must have taken on the obligation to care for the person in danger. ${ }^{*}{ }^{6}$ That applies, for instance, to a doctor providing treatment or a caretaker providing care to a certain person. It means that a doctor or caretaker is no-one's guarantor solely by dint of profession. For instance, a doctor or a caretaker who fails to provide assistance to a person in a life-threatening situation on a street or while visiting a medical care institution where he or she does not work shall not be liable for completed or attempted manslaughter. In such cases, only liability under \$124 (1) of the PC can apply. Since the formation of guarantor status requires adoption of a duty of care, an employee of a care institution cannot be deemed a guarantor for the care patients at that institution merely on account of the fact of working there. ${ }^{*} 37$ Failure to take restraint measures may thus lead to liability of a caretaker acting as a guarantor for manslaughter by omission - for example, when a care patient incapable of comprehending cuts his or her

32 T. Kaukvere. Tapmine Wismari haiglas tõi ilmsiks puudused terviseameti töös ['Murder at Wismari hospital revealed shortcomings in the work of the Health Board']. - Postimees, 10.11.2015 (in Estonian). Available at http://www.postimees. ee/3393299/tapmine-wismari-haiglas-toi-ilmsiks-puudused-terviseameti-toos (most recently accessed on 25.5.2017).

33 With regard to one suicide case of this nature, see the Chancellor of Justice's memorandum of 9.11 .2015 on deaths at special care homes, para. 8. Available, in Estonian, at http://www.oiguskantsler.ee/sites/default/files/field_document2/6iguskantsleri_ ettepanek_rikkumiste_korvaldamiseks_surmajuhtumid_erihooldekodudes.pdf (most recently accessed on 25.5.2017).

34 Leaving in danger and failure to provide assistance are absorbed into manslaughter; see, respectively, A. Schönke, H. Schröder (see Note 11), Art. 221, Comment 18 (A. Eser, D. Sternberg-Lieben) and the memorandum: ibid. See also Stuff Missing Here, Art. 323c, Comment 30 (D. Sternberg-Lieben, B. Hecker).

35 On the division of the guarantor obligation into protection and guarding guarantor obligation, see, for instance, J. Sootak. Karistusõigus. Üldosa ['Penal Law: General Part']. Tallinn 2010 (in Estonian), Ch. XI, refs 39-40.

36 R. Rengier (see Note 13), Art. 50, refs 28-31; T. Fischer (see Note 6), Art. 13, Comment 14; J. Sootak, P. Pikamäe (see Note 8), §13, Comment 7.2.2 (J. Sootak).

37 At the same time, a position has been expressed in Germany that care staff act as protection guarantors with respect to the care patients; see R. Rengier (see Note 13), Art. 50, Ref. 31. 
veins and the caretaker fails to stop that act or the ensuing events in any way (whereupon the patient dies) or when one of the care patients beats another and the caretaker fails to intervene (whereupon the patient who was beaten dies). However, liability for manslaughter by omission is probably out of the question in cases in which a caretaker has left a bound care patient alone with other patients or left unattended a care patient who has suicidal tendencies. That is because, even if the caretaker had intention with regard to the dangerousness of the situation (which is disputable), he or she probably had no intention as to the arrival of death.

Heads of care institutions (e.g., board members of a legal entity) cannot be considered caretakers, because they are not directly involved in taking care of specific patients and are responsible instead for ensuring the proper functioning of the institution. That said, a duty to act is not entirely ruled out. However, in their case, the status of guarding guarantor may be considered rather than that of protection guarantor - their duty is not to protect the specific care patient but to ensure the source of threat under their responsibility not causing any damage (i.e., they have to guard the source of threat). The care institution as such might be such a threat. Just as organisers of a racing competition must ensure the safety of the spectators ${ }^{*} 38$, the equivalent must be done by heads of care institutions for the people cared for in such institutions. Therefore, if an institution head sees a care patient lying in the yard in the cold and at least accepts the possibility of the latter freezing to death yet fails to take action, he or she is liable for the manslaughter of the patient by omission. If the care patient indeed dies, liability for the completed act follows under $\S \S 113$ (1) and 13 (1) of the PC; however, if the patient survives for whatever reason, the head of the institution shall be held liable for attempted manslaughter by omission under $\S \S 113$ (1), 13 (1), and 25 (5) of the PC.

The foregoing notwithstanding, liability of caretakers for causing death through negligence (omission) is still more likely. It needs to be considered that liability under negligence terms can follow only when a person violates some sort of duty of care - i.e., does not show the care required of him or her. The arrival of the consequence constituting the offence must be foreseeable. ${ }^{*} 39$

Therefore, in a situation in which a caretaker leaves a care patient without supervision and something negative happens (e.g., the patient dies), the caretaker can be held liable in having violated the duty of care by leaving the person without supervision. When discussing the supervision duty of caretakers, we can agree with the position repeatedly expressed in German (civil) case law that the requirements set for care institutions cannot be so strict that they would render financially affordable dignified care impossible. ${ }^{*} 40$ Financial considerations render it impossible to ensure constant monitoring of the care patients; hence, failure to supervise is not in itself a violation of the duty of care. The required minimum level (below which there is a violation of the duty of care in cases of relevant damage under penal law) probably changes over time - the further a society evolves and the richer it gets, the higher are the requirements set for care institutions.

Failure to monitor can be deemed violation of the duty of care firstly when there are specific references to the possibility of a negative consequence. This occurs, for instance, when a care patient unable to comprehend and left alone has (repeatedly) attempted suicide before and kills him- or herself. Violation of the duty of care can be affirmed also in a situation wherein a caretaker leaves care patient A in a room with care patient B who has a history of (repeated) violence, whereupon B kills A. However, if B in his or her many years with the institution has not been violent before, the caretaker could not have foreseen the act of violence by B and did not violate the duty of care by leaving A in the same room as B.

Nonetheless, a duty of care may arise otherwise too, from the special provisions ${ }^{*}{ }^{41}$ : provisions on how to perform a certain action as safely as possible. ${ }^{*} 42$ For example, the second sentence of $\$ 107$ (2) of the SWA provides that the person in question shall be constantly under the supervision of the provider of 24-hour special care services during that person's stay in an isolation room, and the second sentence of $\S 14^{1}$ (1) of the MHA establishes that upon the use of mechanical restraint, the person restrained shall be under constant

38 R. Rengier (see Note 13), Art. 50, Ref. 50 (Rengier still considers it possible to deem an organiser of a race also a protection guarantor for spectators).

39 On the concept of duty of care, see, for example, J. Sootak, P. Pikamäe (see Note 8), §18, Comment 9 (P. Pikamäe).

40 For references to judicial decisions, see F. Henke (see Note 7), pp. 35, 63, 65; C.W. Schmidt (see Note 16), p. 165, Footnote 778 .

41 The term 'special duty to care’ has been used in the legal literature; see J. Sootak, P. Pikamäe (see Note 8), §18, Comment 9.2 (P. Pikamäe).

42 The most well-known example is the Traffic Code - it consists almost entirely of special provisions in the meaning of negligence delicts (that is, it explains the duty to care in traffic). 
supervision by a health-care professional. There are solid grounds for presuming ${ }^{*} 43$ that if the caretaker fails to comply with these provisions and the care patient dies, the case in question constitutes a violation of the duty of care by the caretaker, which should bring about the caretaker's liability for causing a death of another person through omission under $\S \S 117$ (1) and 13 (1) of the PC. In addition, under the rules of a perfect aggregate (see $\S 63$ (1) of the PC), caretaker liability under Section 124 or 123 of the PC may be considered, because causing death through negligence does not constitute intentionally leaving another person in a dangerous situation.

According to $\S \S 117$ (1) and 13 (1) of the PC, the head of the care institution too may be held liable for a care patient's death, for reason of having failed to organise the work of the institution in a sufficiently secure manner, thereby violating his or her duty of care. For instance, in the above-mentioned case of a care patient freezing to death, the head of the care institution could be accused of having used so-called non-foolproof front doors to save money. Another accusation that could arise is that of not having been sufficiently diligent in selecting the staff, with this having led to a) the negligent caretaker not keeping an eye on the care patient as he or she was supposed to, instead allowing the patient to go out in the cold, or b) the caretaker leaving the suicidal care patient alone because of not having received sufficient training or there not being enough staff available. ${ }^{*} 44$

Finally, a self-evident aspect with regard to the general part of the Penal Code should be reiterated: several persons could be held liable for causing a single consequence, and only some of them might have participated. Hence, for unlawfully depriving a care patient of liberty, not only the caretaker who locked the person in a closed room should be held liable but so too shall the supervisor who gave the order to do so: the caretaker shall be liable under $\$ 136$ (1) of the PC as a principal offender and the supervisor under $\S \S 136$ (1) and 22 (2) of the PC as an abettor.

\section{Preclusion of unlawfulness of means of restraint}

When someone commits an act that possesses all the necessary elements of an offence, it can be presumed to be an offence because the presence of the necessary elements indicates unlawfulness. However, in exceptional cases, an act can possess these elements without actually being unlawful. This occurs when certain circumstances of the case preclude unlawfulness. Unlawfulness can be precluded by grounds stemming from several sources, some specified in the Penal Code, many of them addressed in other laws, and some not articulated in legislation.

The admissibility of means of restraint as bringing about the necessary elements in the above connection may depend on various circumstances. This section of the article firstly addresses the general circumstances that preclude unlawfulness - that is, the ones that arise not only in care institutions but nearly everywhere else too. After that, specific circumstances that preclude unlawfulness are analysed, the ones relevant only in the context of our topic.

\subsection{Compliance: Consent and permission}

We begin this section of the article by discussing the person's compliance with being restrained. Namely, penal-law theory holds that when the holder of the legal right does not deem that legal right worth protecting, the state is not to protect it forcibly. ${ }^{*} 45$ That said, compliance generally can justify only such restraining as is in the interests of the care patient - in rather exceptional cases it can be said that the patient accepts being restrained because of posing a threat to someone else (e.g., a care patient in a moment of clarity tells

43 In (extremely) exceptional situations, however, violation of the special provision and failure to comply with the duty to care may not coincide. See R. Rengier (see Note 13), Art. 52, Ref. 17; J. Wessels, W. Beulke. Strafrecht. Allgemeiner Teil. 37. Aufl. ['Criminal Law: General Part, 37th Ed.']. Heidelberg, Germany, 2007 (in German), Art. 15, Ref. 672.

44 See the 27.2.2014 summary of the Chancellor of Justice's inspection visit, 'Kontrollkäik AS-i Hoolekandeteenused Valkla Kodu' (or 'Visit to AS Hoolekandeteenused Valkla Kodu'), section 4.1. Available, in Estonian, at http://www.oiguskantsler. ee/sites/default/files/field_document2/kontrollkaigu_kokkuvote_as_hoolekandeteenused_valkla_kodu.pdf(most recently accessed on 26.5.2017).

45 W. Gropp. Strafrecht. Allgemeiner Teil. 4. Aufl. ['Criminal Law: General Part, 4th Ed.']. Berlin 2015 (in German), Art. 5, Ref. 74. 
a caretaker that if he or she should ever lose the ability to comprehend, he or she should be bound with restraint straps in the event of posing a threat to other people).

Although Estonian law generally refers to consent in connection with compliance, equating the two is not suitable for our discussion, since the theoretical grounding of this article lies largely in German law. The reason is that German jurisprudence differentiates between two types of compliance - firstly, one called Einverständnis in German and glossed in the Estonian environment as consent and, secondly, Einwilligung, which is referred to in Estonian via the concept of permission ${ }^{*}{ }^{6}$. In German law, it has been found that in some cases compliance in the sense of consent inherently excludes appealing to the necessary elements for an offence and that in other cases compliance in terms of permission excludes the unlawfulness of the act. ${ }^{*} 47$ The constituent elements of an offence are excluded by dint of compliance (consent) when the unlawfulness linked with the constituent elements lies in the fact that the act is committed against the will of the person or without the person's consent. On the other hand, generally, forbidden attacks damaging another person's legal rights (e.g., attacks on physical integrity) represent at least prima facie abstract unjustness, the elimination of which must take place on the level of the attacks themselves being unlawful. ${ }^{*} 48$ Among the most relevant special-part compositions in the context of this article, deprivation of liberty and physical abuse are seen quite differently by the German scholars when they are addressing compliance - in cases of deprivation of liberty, compliance (consent) excludes constituency ${ }^{* 49}$; in cases of physical abuse, unlawfulness is excluded for reason of permission on the basis of an explicit legal provision, Section 228 of the German Penal Code (Strafgesetzbuch, or StGB). Differentiating between the two is important because consent is associated with more lenient requirements than permission is. Accordingly, when a person meets the conditions both for having been deprived of liberty and for his or her physical integrity having been breached, deprivation of liberty may be non-punishable for reason of consent while the breach of physical integrity may still be punishable as physical abuse if the potential permission does not comply with the requirements in question. Within the space of this article, it is not possible to analyse whether following this theory (i.e., differentiation between consent and permission) would be justified in Estonia. Nevertheless, the distinction will be maintained below.

A person can comply with something only when truly capable of compliance. In Germany, there are significantly stricter requirements for showing capacity for compliance in cases of permission than in cases of consent. In the latter, the person's natural will ${ }^{*} 50$ is sufficient; i.e., if the 'victim' complies in fact with the act, the constituent elements do not obtain. ${ }^{*}{ }^{1}$ For instance, theft is excluded when a toddler or a mentally ill person voluntarily gives away his or her belongings, even if that act was completely irrational in objective terms. ${ }^{*} 52$ When we take as part of the basis the fact that $\$ 136$ (1) of the PC indicates the sufficiency of consent based on natural will (see the preceding paragraph), one consequence in our case is that the constituent elements of deprivation of liberty are not present in any case if the care patient consents to it. ${ }^{*} 33$ Therefore, caretakers would need to seek other legitimisation for deprivation of a care patient's liberty in the interests of the latter only if the care patient does not consent to being deprivation of liberty (as when a patient who is locked inside a room cries or expresses a wish not to be locked in to the person who closes the door). However, in a case of permission precluding unlawfulness, natural will alone is insufficient - the permission is valid only if the person has the capability to express that permission (the German Einwilligungsfähig). Nevertheless, excessively high-threshold prerequisites cannot be set for this capability. The capability does

46 J. Sootak (see Note 35), Ch. VII, Ref. 306.

47 See the overview in Estonian by J. Sootak (see Note 35), Ch. VII, refs 301-339.

48 E. Hirsnik. Mõningatest karistusõiguslikest inimese surma põhjustamise, vabaduse võtmise ja kuriteo varjamisega seotud probleemidest ['On some issues pertaining to causing death of a person, deprivation of liberty, and non-disclosure of criminal offence under penal law']. - Juridica 2011/2, pp. 153-161 (in Estonian), on pp. 158-159 (with succeeding references), addressing the decision of the Criminal Chamber of the Supreme Court in case no. 3-1-1-57-10.

49 W. Gropp (see Note 45), Art. 5, Ref. 113; J. Wessels, W. Beulke (see Note 43), Art. 9, Ref. 366.

50 The concept of natural will was relatively recently used by the Supreme Court for the first time as well; see CCSCr 3-1-1-10815, para. 16.2 .

51 J. Wessels, W. Beulke (see Note 43), Art. 9, Ref. 367; R. Rengier (see Note 13), Art. 23, Ref. 45.

52 Ibid.

53 This is the logic on which German civil law too is based. Subsection 1906 (3) of the German Civil Code (Bürgerliches Gesetzbuch, BGB) states that employing means of restraint in the interests of the person being restrained is, first and foremost, justified when it is in compliance with the natural will of the person. Only when it is not is there a need to search for other legitimisation (permission of the guardian). 
not depend on the person's age or on having (full) active legal capacity under civil law. The deciding factor is whether the person can actually understand (i.e., possesses the capacity of understanding) the meaning of the permission. ${ }^{*} 54$ Whether that permission is reasonable in the eyes of a third party is not important. ${ }^{*} 55$

Often, people at care institutions are not capable of giving legally relevant permission from the standpoint of precluding unlawfulness, since they do not comprehend the substantial meaning of their permission in a sufficient manner. ${ }^{*}{ }^{6}$ Importantly, though, this is not always the case. For instance, a care patient may be capable of comprehending the meaning of some simple measures (e.g., understanding that he or she needs to take a certain medicine for avoiding the danger of falling out of bed at night) but nothing more complex. Therefore, the care patient may not be incapable of providing permission as such: it is possible to be able to give permission for some measures but not for others. The foregoing discussion makes it clear that people under guardianship too can be capable of giving permission. ${ }^{*} 57$

In the case of a composition in which compliance rules out unlawfulness of the act (e.g., §121 of the PC) where a care patient who is capable of supplying permission does not do so, the caretaker shall not perform the act encompassing the necessary elements of an offence (in the interests of the care patient), such as force-administer a sedative to the person. If the caretaker does this nonetheless, it is an offence (provided that the caretaker is at fault). The caretaker is, for instance, unable to rely on necessity ( $\$ 29$ of the PC) and justify the act with the statement that he or she has prevented significant damage (even death in extreme cases) by medicating the patient, because a person's free will must be respected. The latter cannot be evaded on grounds of the principle of proportionality. ${ }^{*}{ }^{8}$ Since there is no actual permission, it cannot be claimed that there is presumed permission, because refusal to provide explicit permission excludes application of the institution of the presumption of permission. Hence, a capable person who refuses a cannula may not be cannulised (the tube causes damage to health) even if not inserting the cannula would mean that the patient would die, not to mention lose consciousness.

While the prevailing opinion in Germany with regard to permission precluding existence of the constituent elements of an offence is that compliance in practice is sufficient, the position related to permission precluding unlawfulness is that the person must express the permission with an act, either directly or concludently. ${ }^{*} 59$

Finally, it needs to be stressed that only the persons themselves can express their conclusion - the position of loved ones (e.g., relatives) is legally irrelevant (even when it is sometimes seen otherwise in the practice of care institutions). ${ }^{*}{ }^{6}$

\subsection{Presumed permission}

German law includes the institution of presumed permission also. Presumed permission is, in fact, a surrogate for permission proper - it can be considered to be justification for an act comprising the necessary elements for an offence when determining the will of the holder of the legal rights is impossible. When one can ascertain the actual state of permission and either doing so or delay associated with trying to do so does

54 W. Gropp (see Note 45), Art. 5, Ref. 80; R. Rengier (see Note 13), Art. 23, Ref. 15; J. Sootak (see Note 35), Ch. VII, Ref. 322.

55 W. Gropp (see Note 45), Art. 5, Ref. 80; C. Fuchs (see Note 24), p. 9; V. Thiel. Freiheitseinschränkende Maßnahmen gegenüber Pflegebedürftigen ['Measures restricting freedom within care']. 2003 (in German), p. 5. Available at http://volkerthiel.de/ wp-content/uploads/2014/10/FreiheitseinschrMassn_12.pdf (most recently accessed on 27.5.2017).

56 F. Henke (see Note 7), p. 24. Nevertheless, it should be noted that Henke does not differentiate between compliance that has the constituent elements of an offence and compliance for which unlawfulness is precluded. This may be related to the fact that the author is not a jurist but a care practitioner and a scientist.

57 F. Henke (see Note 7), p. 24.

58 R. Rengier (see Note 13), Art. 23, Ref. 5; C.W. Schmidt (see Note 16), p. 154; also see Subsection 3.4 of this article.

59 J. Wessels, W. Beulke (see Note 43), Art. 9, Ref. 368, 378; R. Rengier (see Note 13), Art. 23, refs 21 and 46. When discussing consent in the context of physical abuse, the Supreme Court of Estonia too has found that the consent must be given directly or concludently; see CCSCd 3-1-1-60-10, para. 17.2.

60 With regard to Germany, see such sources as C. Fuchs (see Note 24), p. 7; V. Thiel (see Note 55), p. 3; F. Henke (see Note 7), p. 27. For discussion related to Estonia, see the summary of the Chancellor of Justice's 10.10.2013 inspection visit titled 'Kontrollkäik SA-sse PJV Hooldusravi' (or 'Visit to the foundation PJV Hooldusravi'), p. 3. Available, in Estonian, at http:// www.oiguskantsler.ee/sites/default/files/field_document2/kontrollkaigu_kokkuvote_sa_pjv_hooldusravi.pdf(most recently accessed on 26.5.2017). 
not cause (more) damage, the person wishing to perform the act entailing the necessary elements for an offence has to find out the will of the person holding the legal right, exercising due diligence. ${ }^{*}{ }^{6}$

Classic examples of presumed permission are operating on an unconscious person on the brink of death and breaking into the house of a neighbour who is on holiday to determine whether the smoke emanating from beneath the front door may indicate fire. In situations of this sort, it can be presumed (expected) that the surgery patient and home-owner would have given permission to operate and to enter the house, respectively, if they had been asked. The existence of presumed permission - which is highly relevant in respect of the topic at hand - also is actualised when the person is in no condition to give permission. Accordingly, for example, depriving a person with a mental disorder of liberty for his or her own protection may be in contradiction with that person's natural will, which is why it is not possible to take permission for granted in this connection. However, presumed permission can be taken as a basis (e.g., the person bangs his or her head against the wall and, to stop that, the person is strapped to a bed without regard for his or her protests). Thus, not providing permission does not eliminate the possibility of applying the institution of presumed permission, unlike refusal to give permission (see Subsection 3.1, above). That is because refusal of a person not capable of giving permission to provide such permission is not based on weighing all the relevant circumstances, while these are precisely what are weighed in cases of presumed permission. In conditions involving restraint, it is probably difficult to imagine situations in which physical distance renders it impossible to seek the permission of the holder of the legal right (as in the example above of the possible fire). The main situations (but not the only ones) that could be considered relevant in this regard are those in which the care patient has no capacity to provide permission.

The less information the caretaker has on a given care patient with no such capacity, the more certain the caretaker can be in basing the related decisions on the assumption that the presumed will of the patient coincides with what is normal and reasonable. ${ }^{*} 62$ In cases of normal and reasonable conduct, the conceptions developed on the basis of necessity can be used as a basis (see Subsection 3.4 of this article).

Firstly, this means that, to eliminate a threat, suitable means should be used that are as conservative in nature (sparing of force etc.) as possible. For instance, if the person has (repeatedly) fallen out of bed while sleeping, both strapping the person to the bed and putting safety rails in place are suitable means for eliminating the threat of falling, but the latter is undoubtedly more cautious. An even more conservative approach would probably be to place the mattress on the floor. Another question is whether the last method mentioned (putting the mattress on the floor) is suitable in the sense of avoiding threats to health in general. A person sleeping on the floor could be tripped over by fellow patients, with injuries resulting, or could roll off the mattress onto the bare floor and catch cold.

The principle of proportionality should be taken into account also. When the threat is low and the potential damage irrelevant, the person's rights should not be restricted in an excessive manner on grounds of preventing the threat. Honouring of the principle of proportionality and the presumed permission of the care patient could probably be affirmed in the following example cases: caretakers immobilise the patient with restraint straps to prevent said patient from removing a cannula and caretakers inject a sedative into a care patient who is banging his or her head against the wall. In both of these cases, caretakers deprive the patient of liberty to protect extremely important legal rights of the patient - to health or even life. The situation would be different, however, if the sedative were to be injected to stop the care patient ripping his or her clothes, because a possession of such low value as clothes certainly does not surpass a person's liberty in value, and it can be presumed that such a care patient would agree if having the capacity to comprehend.

In contrast, in a situation wherein a caretaker is able to proceed from the knowledge available and presumes that the patient would not wish to be restrained, restraint must be avoided even if doing so seems unreasonable. Just as it is necessary to determine the actual will of the holder of the legal right when possible (i.e., obtain permission; see above), one must undertake the efforts necessary to determine his or her presumed will, so as to find out whether that presumed will is indeed in line with a normal and reasonable understanding. Whether such presumed will differs from the average (or what is normal) can be determined in several ways. One of the possibilities is to talk to people who know the care patient, such as relatives, and find out whether the person discussed the details of his or her care (and situations in which the person's

61 W. Mitsch. Die mutmaßliche Einwilligung ['The presumption of consent']. - Zeitschrift für das Juristische Studium 2012/1, pp. 38-43 (in German), on p. 41.

62 BGHSt 45, p. 221 (ref. to R. Rengier (see Note 13), Art. 23, refs 58-59); BGHSt 35, p. 246 (ref. to J. Wessels, W. Beulke (see Note 43), Art. 9, Footnote 46). 
rights should not be interfered with) when still capable of comprehension. Here, it is important to note that the care patient's own opinions at the time of comprehension ability (if available), not the opinion of the relatives at the time of questioning, must be found out. Again, the position of the relatives themselves is irrelevant. In Germany, a so-called patient order (Patientenverfügung) or autographic guardianship authorisation (Vorsorgevollmacht) may be used, in which a person of capacity to comprehend describes what may and may not be done to him or her in the event of illness, in the first case, or, in the second, who should care for him or her if care becomes necessary and what said carer(s) may do. In both cases, the person attesting considers the situations in which he or she is no longer able to express his or her will or form a clear understanding. At least generally, the wishes written down in this document can be equated with the presumed will of the care patient, making it binding for the caretakers. The presumed will of the patient can be deemed to diverge from this only in exceptional circumstances - for instance, when the person expressed a different will to caretakers upon first arriving at the care institution in a condition in which he or she still was capable of expressing the relevant permission. In addition, caretakers may ask a person who still has comprehension capacity about the conduct that person would expect from caretakers in various sets of circumstances, before the situation becomes critical $^{*}{ }^{6}$. In such a case, when a situation of the type discussed arises, it can be presumed that the person's wish is the one expressed to the caretaker.

When a caretaker commits an act that possesses the necessary elements of an offence on the basis of presumed permission (e.g., holds down a person who was beating his or her head against the wall; see $\S 136$ (1) of the PC), it is lawful. Later protests of the care patient do not make it unlawful. If later opposition to the methods used is expressed by a person with no capacity to comprehend, that in itself is irrelevant. At the same time, however, even a later protest expressed by a person able to comprehend has no relevance. For instance, a person with such capacity may have agreed to being injected with a sedative to prevent an anxiety attack he or she fears, then, for whatever reason, states on the following day that the injection should not have been performed. The protest does not change the presumed permission at the time of performing the act. ${ }^{*} 4$ However, when a caretaker commits the act while aware of (or accepting, under §16 (4) of the PC) there being no presumed permission, the act is unlawful. In the case of a caretaker holding down a person who is banging his or her head against the wall, when that is not what the person presumably prefers, these actions of the caretaker constitute an offence (in a case of fault) under $\$ 136$ (1) of the PC. Furthermore, the caretaker may not use the excuse of possibly being held liable in the event of failure to act as the guarantor of the care patient, for offence through omission (e.g., under $\S 121$ (1) and 13 (1) of the PC). The reason is that if the holder of the legal right does not (presumably) wish that right to be protected, the caretaker incurs no obligation to act as a guarantor, irrespective of possessing guarantor status - i.e., having a legal obligation to act within the meaning of $\$ 13$ (1) of the PC. ${ }^{*} 65$

\subsection{Self-defence}

The unlawfulness of an act comprising the necessary elements of an offence can be excluded also for reason of self-defence. According to §28 (1) of the PC, the act (when the necessary elements of an offence are present) is not unlawful if the person in carrying it out is combating a direct or immediate unlawful attack on the legal rights of the person or of another person by violating the legal rights of the attacker and without exceeding the limits of self-defence. Therefore, the permission of the care patient or presumption of permission is not relevant in cases of self-defence because the care patient has acted counter to another person's legal rights and, naturally, cannot give permission for this infringement of rights even if/when at full capacity to comprehend.

63 F. Henke (see Note 7), p. 25; V. Thiel (see Note 55), p. 4.

64 R. Rengier (see Note 13), Art. 23, Ref. 51.

65 Nevertheless, it should be noted that there have been some heated arguments in German legal circles as to whether a person acting as a guarantor (e.g., a doctor or a spouse) should exceptionally be obliged to act as a guarantor when a person who attempted suicide has become unconscious. The Federal Court affirmed the incurring of such an obligation (BGHSt 2, p. 150; 32, p. 367, available, in German, at http://www.servat.unibe.ch/dfr/bs032367.html, most recently accessed on 27.5.2017), but the legal literature maintains a firm position that said obligation cannot arise. See the summary by K.E. Hemmer, A. Wüst. Strafrecht BT II ['Criminal Law: BT II'], Chapter I ('Tötungsdelikte. Fall 1: Die lebensmüde Patientin', or 'Case 1: The suicidal patient'). 2015 (in German), p. 3. Available at https://www.hemmer-shop.de/produkt_pdf/44_wichtigsten_faelle_StrafR_ BT_II.pdf (most recently accessed on 16.7.2018). 
The verification of self-defence takes place in two stages. Firstly, it needs to be determined whether there was a direct (including immediate) unlawful attack against some individual-level legal right (whether of the person doing the defending or of another person). If there was, one must consider whether protecting the self or the other person against that attack remained within the limits established by the law.

An attack is any kind of endangerment of or damage to a legal right of a person by another person ${ }^{*} 66$. This might involve a beating or stabbing but also covers insulting someone. An attack is unlawful when it is not legally allowed. For instance, when a police officer arrests a thief caught in the act (depriving the thief of his or her liberty within the meaning of $\$ 136$ of the PC), this constitutes an attack, but such attacks are legitimate according to $\$ 217$ (2) 1) of the Code of Criminal Procedure (CCP) ${ }^{* 67}$ (on detention of someone as a suspect); that is, they are not unlawful. Therefore, the thief cannot legitimately defend him- or herself against the police officer in reliance on claims of self-defence. Only an attack by which the attacker threatens or damages someone else's legal right intentionally or at least by violating some sort of duty of care is unlawful. When a driver is complying with the Traffic Code but hits someone with the vehicle nevertheless (e.g., children at play who run into the road from behind some trees just for fun), the conduct of the driver (i.e., the driving) is not an unlawful attack against the children's legal rights (to life and health). ${ }^{* 68}$ The unlawfulness of an attack is not ruled out by the attacker's no-fault conduct (i.e., the attacker being unable to comprehend that the act is prohibited or being unable to direct his or her actions even if understanding that those actions are not allowed). Example cases might involve an attacker who is a child or has a mental disorder: self-defence is allowed against attacks by such people. Therefore, caretakers can assert self-defence even when the care patient who threatens or has already impinged on the legal rights of other people is incapable of understanding the meaning of his or her action in consequence of, for instance, a mental disorder. The caretakers are allowed to defend not just themselves but also other people, such as other care patients - as guarantors, they may even be obliged to defend them, in line with the discussion above - or visitors to the institution. Also, they may defend items not belonging to the attacker (e.g., property of the institution). For this, the attack has to be direct. There are no grounds for claims of self-defence in the case of a caretaker binding a care patient with restraining straps or locking the patient in a separate room when the patient, although having attacked someone, stopped the attack.

It then needs to be determined what is allowed under self-defence grounds, along with the extent to which it is permitted. In relation to this, we need to draw attention firstly to a certain banality related to self-defence that is taught to university students from the first lectures on penal law onward but that, in the authors' estimation, is not understood by most lawyers until late in their career: there is no principle of proportionality in self-defence law. In this, there is a difference from necessity, in the case of which committing an act that involves the necessary elements of an offence is justified only when 'the interest protected is evidently of higher importance than the interest subject to damage' in the words of $\$ 29$ of the PC. Self-defence differs from situations of necessity principally because no legal rights are weighed. There is a principle that law shall not back down to unlawfulness ${ }^{* 69}$. This is behind the theoretical permissibility under $\S 28$ of the $\mathrm{PC}$ of someone severely injuring or even killing a person who has insulted him or her or who attempts to run away with a wallet stolen from that person. No importance is accorded to the fact that a human life is fundamentally of incomparably greater importance than property of low value (a wallet, whatever the contents) or honour (damaged by an insult).

Subsection 28 (1) of the PC confers on a person the right to combat an attack. According to legal dogmatics and case law, an attack may be combated in a manner that is appropriate and cautious/conservative. Appropriateness entails combating that brings the attack to an end completely and immediately or at least reduces the damage caused to the legal right by the attack. ${ }^{* 70}$ Such a criterion can be derived from the very concept of combating: if the act does not at least make the attack harder in some way, it cannot be deemed combating. Caution involves a requirement of selecting whichever of the suitable defensive actions (means of defence) is the least damaging to the legal rights of the attacker, which may be referred to as the most sparing one. ${ }^{*} 71$ Finding content in the law for the sparingness requirement is more complicated than the

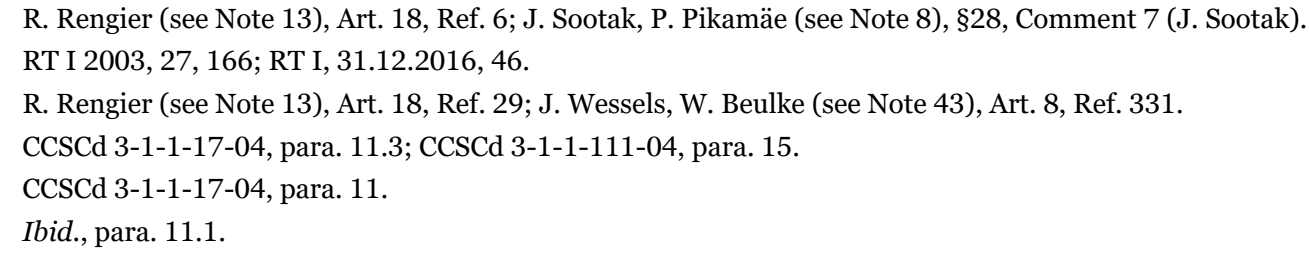


equivalent for the appropriateness criterion. The definition of combating says nothing about the fact that the defender shall not select the most intense means available - in figurative terms, opt for an antitank weapon instead of punching the attacker. Finding a basis for the criterion of sparingness is easier under German law (Subsection 32 of the StGB), because it refers to necessary defensive actions: if the attack can be stopped with a simple punch, there is no need for an antitank defence weapon. ${ }^{*}{ }^{72}$ The Supreme Court of Estonia has attempted to justify a requirement of sparingness in case no. 3-1-1-17-04 by using two arguments. Our highest court has referred to §28 (2) of the PC (in para. 11.2 of the judgement), which establishes that a person is deemed to have exceeded the limits of self-defence if, with deliberate or direct intent, having carried out the defence by means that are clearly incongruous with the danger arising from the attack or if having, again with deliberate or direct intent, caused clearly excessive damage to the attacker. Nevertheless, it needs to be noted that §28 (2) of the PC itself says nothing about the objective elements of self-defence. It regulates only the subjective elements. The second argument, found in the statement (in paragraph 11.1 of the judgement) that the attacker must not place him- or herself outside the law (i.e., must not become an outlaw), is more convincing. In addition, there may be some grounds for relying on the constitutional principles of human dignity and general proportionality: if the attack can be combated with a mild measure, use of an intense means cannot be justified under the principles of the rule of law.

In the context of care institutions, the above means that caretakers are allowed to stop an attack by a care patient but need to do it in a way that is the least damaging to the legal rights of the care patient. If the problematic activity of a raging care patient can be ended by wrestling the patient to the ground, it should be done. What shall not be done is, for example, hitting the care patient in the head with a chair. This action with a chair, however, is justified if forcing the patient to the ground would not stop the attack and, hence, would not be appropriate - for instance, when the attacker is a big, strong man and the defender a petite female caretaker. Locking a care patient inside a room also can be considered a defensive action. In extreme cases, the requirement of sparingness could be in accord even with killing the care patient. The patient may, for example, have gained possession of a knife and either have started stabbing someone or be about to do so.

Legal scholars have found that, in exceptional cases, the extremely wide and powerful (with its lack of proportionality requirement!) self-defence right should be restricted for socio-ethical reasons. ${ }^{*} 73$ Also, the Supreme Court has found that the principle of solidarity that holds a society together requires some withdrawal of a person's right to self-defence if its exercise to the full would bring about violation of rights and unbearable socio-ethical conflict. ${ }^{*}{ }^{4}$ For instance, in cases of low-risk unlawful attacks, it is required that the defender avoid the attack regardless of §28 (3) of the PC or confine him- or herself to only moderate (sparing of the attacker) means of defence. ${ }^{*} 75$ Where such possibilities are lacking, the person being attacked is even under obligation to tolerate the damaging of a low-value right in some cases, when the only means of defence would bring about exceptionally disproportionate damage to the rights of the attacker as compared to the rights being defended (e.g., the owner may not shoot an apple thief who is escaping with the loot, even if this is the only way of getting back the stolen fruit). ${ }^{*}{ }^{6}$ Even in this connection, it is complicated to state in Estonia (as in case of the sparingness requirement) that these socio-ethical limitations can be derived from a norm regulating the right to self-defence, because $\$ 28$ of the PC refers to no such thing. It is different in Germany: Section 32 (1) of the StGB states that the self-defence actions must be necessary. ${ }^{*} 77$ The Supreme Court of Estonia has derived its corresponding restrictions from $\$ 19$ (2) of the Constitution, establishing that when exercising his or her rights and freedoms and fulfilling his or her duties, everyone must respect and honour the rights and freedoms of others. ${ }^{*}{ }^{8}$

The authors of this article are not aware of any case law in Estonia that addresses the socio-ethical boundaries of self-defence. That is why it is suitable to look to German law (and the Estonian legal literature referring to it). German law differentiates among four groups of cases in which defence activities are

\footnotetext{
72 It should be noted that Estonian legal dogmatics has taken over the German definitions; see J. Sootak, P. Pikamäe (see Note 8), §28, Comment 15 (J. Sootak); J. Sootak (see Note 35), Ch. VII, Ref. 155 ff.

73 J. Sootak, P. Pikamäe (see Note 8), §28, comments 21-25 (J. Sootak); J. Sootak (see Note 35), Ch. VII, Sidenote 172 ff.

74 CCSCd 3-1-1-111-04, para. 15.

75 Ibid.

76 Ibid

77 This concept has been transposed into Estonian legal dogmatics; see J. Sootak, P. Pikamäe (see Note 8), §28, comments 21-25 (J. Sootak); J. Sootak (see Note 35), Ch. VII, Ref. 172 ff.

78 CCSCd 3-1-1-111-04, para. 15.
} 
restricted on socio-ethical grounds. These are bagatelle attacks, attacks in close relationships (such as those within a family), provoked attacks, and no-fault attacks. ${ }^{*} 79$ In some instances, the associated grounds may overlap.

The German Federal Court has developed a theory that involves three stages for situations such as these. ${ }^{*} 80$ The first stage to consider is that in which one can run away or call for help, the Estonian kutsumine. The law must bow in the face of the unlawful act committed because when assistance can be summoned, the extent of the unlawfulness is not as great as is usual in cases of unlawful attacks. When escaping or calling for help is impossible - i.e., in the second stage - a weapon of defence should be used. For instance, the blows from the attacker should be blocked with an arm or an object, such as a chair. Use of such a weapon could be required also when the outcome is uncertain and may entail risks. ${ }^{* 81}$ In a concrete example, it may be necessary to hold the attacker down by force, risking the attacker breaking free and attacking again, instead of neutralise the attacker right away (e.g., hitting this person in the head with a bat, stabbing the attacker, or shooting him or her). Active defence (that is, harming the attacker) is allowed only as the last resort. In some cases, however, defence should be abandoned altogether. ${ }^{*} 82$

Let us consider the bagatelle case. When a legal right of low value is attacked and defending that right would require damaging an important legal right (e.g., A grabs B's wallet and runs away with it, where A is a faster runner and the only way for B to get the wallet back is to shoot A with a pistol, so B does so with indirect intent to kill), application of the principle by which the proportionality principle does not apply with regard to self-defence law is restricted. With regard to situations in which there is great inequality in the weight of the legal rights at issue, it has been found in Estonia that defensive actions are not required law has to retreat from unlawfulness. At the same time, this is a highly exceptional case that does not refute the understanding that (normally) the proportionality principle is not recognised with regard to the right of self-defence. In Germany, it has been found that the cost of a human life is closer to 100-200 euros than around 500 euros in situations of this nature. ${ }^{*} 83$ In the above example, this means that if B's wallet contains less than 100 euros, B has to accept losing the wallet, while with an amount close to 200 euros, not to mention 500 euros, B is allowed to shoot.

In cases of care institutions, the following could be deduced in relation to attacks of various sorts. When an attack by a care patient poses a threat to someone's health (e.g., fellow patients' or caretakers'), let alone someone's life, depriving the care patient of liberty is allowed without any problems arising. Liberty as a legal right definitely does not have more weight than health. Damaging the attacker's health or even taking his or her life is justified for bringing an end to attacks that harm health because it is a highly important legal right. Only in quite specifically delineated cases must the defender abandon the option of killing the attacker or causing serious damage to the attacker's health, therein tolerating the damaging of his or her own health (or somebody else's). One of these is a situation in which the person attacked is faced with only relatively mild health damage. In contrast, a case of (intense) beating cannot be deemed one of a bagatelle attack that should be tolerated. Also when a care patient is breaking items stocked by the care institution, depriving the patient of liberty and causing that patient mild (or moderate) health damage is generally deemed lawful. Nevertheless, it might be unlawful if the material broken had very low value.

In the context of the topic considered here, an important factor is that the right to self-defence is restricted also in cases of no-fault attacks - i.e., in situations in which the attacker is a child or a person with a mental disorder. The three-stage theory should be taken as a foundation in this connection as well. It has to be noted that if we were to proceed only from the bagatelle dogmatics, damaging the attacker's legal right would be acceptable in the third stage. However, the no-fault nature of the attack may mean in reality that the defender has to accept the damage to the legal right that is under attack. Namely, there is a significant difference in assessment of the act's unlawfulness between a case wherein a 200-euro item is broken by a person who has capacity to comprehend and one in which the person lacks this capacity. Accordingly, a position can be taken that when the care patient is mentally incompetent, the caretaker may not cause him or her serious harm, let alone fatal harm, even when the patient destroys items worth more than 200 euros

79 R. Rengier (see Note 13), Art. 18, Ref. 57 ff.; J. Wessels, W. Beulke (see Note 43), Art. 8, Ref. 343 ff.

80 See, for example, H. Otto. Grundkurs Strafrecht - Allgemeine Strafrechtslehre. 7. Aufl. ['Basic Course in Criminal Law: General Criminal Law, 7th Ed.']. Berlin 2004 (in German), Art. 8, Ref. 79.

81 R. Rengier (see Note 13), Art. 18, Ref. 56.

82 Ibid.

83 Ibid., Art. 18, Ref. 59. 
that do not belong to him or her. Under the three-stage theory, a caretaker may also not start physically defending self or others from insults by a mentally ill care patient - the caretaker has to take the insults, leave the patient, or remove the person who has become a target of the first patient's insults. ${ }^{*} 84$

In Estonian legal literature, an opinion has been expressed that requiring police officers or paramedics to follow the three-stage theory would mean placing an excessive legal burden on them. ${ }^{*} 85$ Such a position cannot be agreed with. Were it to be found that the three-stage theory applies under Estonian law too, the addressees of legal provisions (both regular people and, for instance, police officers and caretakers) would have to follow it. If they are unfamiliar with the theory (which could probably be said of almost everyone) and act in a manner contrary to it (e.g., not running away from an attack by a mentally ill person but combating it by causing harm to the attacker) under an assumption that they are allowed to combat the attacker, they do act unlawfully but in error of law within the meaning of $\$ 39$ (1) of the PC. Error in law relieves a person from liability only when the error was inevitable. Generally, it is not considered inevitable, and the rule of thumb is that ignorance of the law does not exempt one from liability. In one instance, it took the Supreme Court 23 years (or 15 years from the entry into force of the Penal Code) to affirm the inevitability of the error of law. ${ }^{* 6}$ That said, a relatively convincing criticism has been published in German legal literature, making the argument that courts rule out the inevitability of error of law too easily. ${ }^{* 87}$ Nevertheless, it should be noted also that the persons who need to be specifically acquainted with the legal provisions that could become important in relation to a certain aspect of life are precisely those who are active in that part of life every day (for example, caretakers at care institutions should know the provisions for restraining).

\subsection{Necessity}

The last circumstance that rules out unlawfulness is necessity. According to the first sentence of $\S 29$ of the $\mathrm{PC}$, an act is not unlawful if the person commits that act in order to avert a direct or immediate danger to his or her legal rights or those of another person and if both the means chosen by the person are necessary for the aversion of the danger and the interest protected is evidently of greater importance than the interest subject to damage. The second sentence of the same section states that in the considering of interests, the importance of the legal rights, the degree of the danger by which they are threatened, and the danger arising from the act shall be taken into account. ${ }^{*} 8$

84 Also V. Thiel (see Note 55), p. 5.

85 A. Soo, J. Sootak. Õiguslik analüüs karistusõigusliku hädakaitse ja hädaseisundi rollist põhiõiguste piiramise alusena lasteasutustes ning hoolekande- ja tervishoiuasutustes ['Legal analysis of the factors of in-home care and emergency situations as grounds for limiting fundamental rights in child-care, welfare, and health-care institutions']. Tartu 2015 (in Estonian), p. 18. Available at http://www.oiguskantsler.ee/sites/default/files/IMCE/oiguslik_analuus_karistusoigusliku_hadakaitse_ ja_hadaseisundi_rollist_pohioiguste_piiramise_alusena_lasteasutustes_ning_hoolekande-_ja_tervishoiuasutustes_2015. pdf (most recently accessed on 27.5.2017).

86 CCSCd 3-1-1-33-16, para. 22.

87 W. Gropp (see Note 45), Art. 13, Ref. 75.

88 In this article, we will not go into detail on what the implications may be of the institution of necessity established in $\S 141$ (1) of the General Part of the Civil Code Act (GPCCA) for penal law. According to that provision, a person who causes damage in order to prevent danger to him- or herself or another person or to property does not act unlawfully if said damage is necessary to prevent the danger and the damage is not unreasonably extensive when compared to the danger. For now, let us just mention briefly that these issues do exist. Namely, §141 (1) of the GPCCA admits more damage than does §29 of the PC: 'if the damage is necessary to prevent the danger and the damage is not unreasonably extensive [when] compared to the danger' rather than the latter's condition of 'the interest protected is evidently of higher importance than the interest subject to damage'. By that, $\S 141$ of the GPCCA is reminiscent of ideas of attack necessity within the meaning of $\S 904$ of the German Civil Code: greater damage may be caused to an object threatening a right than the value of the right threatened (e.g., an owner of a mongrel may kill someone's expensive pedigree dog that attacks the mongrel). The first issue with §141 (1) of the GPCCA is that the provision does not state that this involves an attack necessity. In accordance with the wording of the law, the mongrel's owner may protect that dog also by, for instance, throwing a neighbour's cat that is completely irrelevant to the situation into the jaws of the attacking dog. That result is unfair, however: why should the mongrel-owner have a right to sacrifice someone else's cat that had nothing to do with the situation? Section 29 of the PC, in contrast, would not allow that, since the mongrel is clearly not more valuable than the cat. German legal practitioners face no such issue, because their legislation differentiates the state of attack from the state of necessity - as already noted, the more extensive state-of-attack necessity is regulated in $\S 904$ of the BGB and the attack necessity, similar to what is addressed in $\S 29$ of the PC, which allows for less liberty, is established in $\$ 228$ of the BGB. The other issue lies in the fact that, while $\S 228$ and 904 of the BGB clearly apply only to objects, $§ 141$ (1) of the GPCCA is somewhat wider in scope, allowing action for combating a threat to oneself, another person, or property. Therefore, in a purely grammatical sense, §29 of the PC could be considered irrelevant and the considerably more favourable $§ 141$ (1) of the GPCCA could be taken as a basis also in cases of weighing 
In speaking about necessity, it needs to be kept in mind that one may appeal to these 'catch-all' circumstances excluding unlawfulness (i.e., this general, extremely wide set of circumstances precluding unlawfulness) only when the terms on other conditions excluding unlawfulness do not apply. ${ }^{*} 89$ Therefore, it can be stated that in the system of circumstances excluding unlawfulness, necessity is lex generalis that is actualised as a secondary option when lex specialis is inapplicable. This means that necessity can rarely be taken as the basis for restraining of patients at care institutions. When restraining takes place in the interests of the care patient, the lawfulness of that restraint should be analysed in terms of the consent of the care patient, permission from the patient (explicit or presumed), or permission of a guardian (see below). If these conditions are not present, restraining is not permissible. For instance, the principle of proportionality shall not be referred to (see Subsection 3.1, above). Therefore, in a situation wherein the action involving the necessary elements of an offence is carried out for the protection of a person who is a source of danger to self, the state of necessity cannot be considered. ${ }^{*} 90$

However, when a care patient threatens someone else's legal rights, the lawfulness of restraining the first person should generally be analysed on the basis of the provisions related to necessity. That said, only when the danger emanating from the care patient does not constitute direct unlawful attack may necessity be considered. Situations of this type are rare. ${ }^{*} 91$ Among them might be cases in which a care patient poses a direct threat to someone but is not an attacker within the meaning of §28 (1) of the PC or is an attacker but does not act unlawfully. To illustrate the first situation (the care patient not carrying out an actual attack), one could cite a case of a sleepwalking patient who starts to bump into fellow patients who happen to be in his or her way. Since sleepwalking is not intentional, it cannot be considered an action within the meaning of the penal code, and non-action cannot be an attack. ${ }^{* 2}$ As for the second class of circumstances, an attack that is lawful may exist in a situation in which a care patient with bad eyesight walks (with full consciousness of walking) toward a patient who has collapsed on a landing without noticing that person on the floor - the person walking poses an objective threat to the other patient because he or she could trip over the patient on the floor and thereby send him or her down the stairs.

Although the foregoing illustration shows that a state of necessity may be considered only under extremely exceptional circumstances in cases of restraint, addressing this topic is still justified. The first reason for this is that understanding the institution of self-defence aids in better understanding the most relevant circumstances that rule out unlawfulness with regard to restraint. Secondly, the definition of immediateness in the sense of $\S 29$ of the PC needs to be analysed: if it were very wide, the state of necessity could probably be used as grounds for restraint quite often.

In comparison of necessity with self-defence, it needs to be kept in mind that necessity is significantly broader than self-defence in one respect while being much narrower in another. Necessity can be taken as a basis in more situations than self-defence can: immediate danger (or emergency) as intended under §29 of the PC occurs somewhat more often than immediate attack within the meaning of §28 (1) of the PC (even if one leaves aside the fact that immediate danger encompasses all instances of immediate attack ${ }^{*} 93$ ). In a contrast against the terms of $\$ 28$ (1) of the PC, dangers to legal rights may be combated in the narrower class of conditions. On the other hand, slightly more leeway may be permitted with regard to self-defence rights than the state of necessity allows, because the latter is greatly restricted by application of the principle of proportionality.

Danger within the meaning of $\S 29$ of the $\mathrm{PC}$ is a situation in which there is strong reason to believe that in the event of countermeasures not being taken, damage is going to occur or the damage is going to increase from what already exists. ${ }^{*}{ }^{4}$ The existence of a threat needs to be assessed ex ante: it is not impor-

legal rights in the event of, for instance, causing bodily injury in the course of combating an attack, instead of §28 of the PC. Therefore, there can be no other conclusion than to find that $§ 141$ (1) of the GPCCA is a legal refuge. It should be stated further to lay to rest discussion of this topic that the Supreme Court of Estonia has only recently had a chance to deal with these issues but decided not to. The unlawfulness of the action of a man who caused different damage to other dogs to protect his own dog from them was analysed under $\$ 29$, whereby the person combating the threat was deduced to have (to some extent) greater rights than the text of the provision actually allows. See CCSCd 3-1-1-60-16.

89 R. Rengier (see Note 13), Art. 19, Ref. 3.

90 C.W. Schmidt (see Note 16), p. 154 (along with subsequent references).

91 See also the definition of a constant threat (in the discussion that follows).

92 J. Wessels, W. Beulke (see Note 43), Art. 8, Ref. 325.

93 R. Rengier (see Note 13), Art. 19, Ref. 4.

94 J. Wessels, W. Beulke (see Note 43), Art. 8, Ref. 303. 
tant what is known to a later assessor (e.g., a judge); what matters is how the situation could be understood at the moment the act (of taking countermeasures) was committed. In this connection, not only the understanding of the person who performed the act should be taken into consideration; so should that of an imaginable objective bystander. ${ }^{*}{ }^{5}$ At the same time, when the person carrying out the act was in possession of some special knowledge, that too needs to be taken into account. ${ }^{*}{ }^{6}$ In the context of our topic, this means that when assessing the danger, one must proceed from an assumption of the average caretaker yet also consider the special knowledge of the person who carried out the specific act in question (e.g., knowledge of a rare disease affecting the care patient that contraindicates certain measures on account of the excessive danger they therefore present).

The concept of imminent threat is highly important with regard to our topic. First and foremost, a threat is imminent when the damage can be expected to arrive immediately (soon). ${ }^{*}{ }^{97}$ In German law and also in Estonia's scanty legal literature in this domain ${ }^{*} 98$, it has been found, however, that, alongside acute threat, permanent threat (Dauergefahr) should be considered imminent. This is represented by a situation wherein the damage could arise at any time while it cannot be ruled out that the damage will not arise anytime soon. ${ }^{*} 99$ An example could involve a building that might collapse at any moment, a head of household who could become violent again at any time, or a case of a mentally ill person. However, the Supreme Court has found that imaginary or potential future threat does not bring about a state of necessity. ${ }^{*}{ }^{100}$ Regrettably, the Court did not provide any additional explanations when making this statement. Because there exists a lasting-danger institution, the question arises of whether residents of care institutions represent immediate danger within the meaning of lasting threat under §29 of the PC. Could it be said that a care patient with a history of violence poses an immediate danger to the other patients and the staff? It is clear that direct attack by the care patient cannot be affirmed in the sense connected with the right of self-defence (see §28 (1) of the PC). At the same time, if one could rely on an understanding that the care patient is a direct threat within the meaning of $\$ 29$ of the PC, such patients could be restrained even when they are not currently aggressive (provided that the other prerequisites for appealing to necessity are met). In any case, one should still agree with the position that lasting danger cannot be talked about in respect of necessity when means restricting liberty are applied as a rule for preventive purposes. ${ }^{*} 101$ Were any other position to be taken, the concept of immediate danger would be stretched so far that it would no longer have any (credible) meaning. Therefore, care patients with a history of aggression who at the moment are non-aggressive can never be deemed an immediate danger within the meaning of §29 of the PC. This is why they may not be routinely locked into their bedrooms/wards for the night in reliance on that provision. ${ }^{*}{ }^{102}$

In the event of immediate danger (i.e., an emergency situation), the danger may be combated, but this is to be permitted only in cases wherein the particular means of combating employed is necessary and the principle of proportionality is observed.

With regard to necessity, the need has to be furnished in a manner similar to that for self-defence - the means of combating has to be appropriate and sparing. As in self-defence, the criterion of suitability is, in general, probably not problematic. The requirement of sparing application needs careful attention here too. In care literature ${ }^{* 103}$, it has been concluded that the first plan of action should be to attempt de-escalation

95 Ibid., Art. 8, Ref. 304; J. Sootak, P. Pikamäe (see Note 8), §29, Comment 4.1 (J. Sootak).

96 J. Wessels, W. Beulke (see Note 43), Art. 8, Ref. 304.

97 W. Gropp (see Note 45), Art. 5, Ref. 223.

98 J. Sootak, P. Pikamäe (see Note 8), §29, Comment 4.1 (J. Sootak); J. Sootak (see Note 35), Ch. VII, Ref. 236.

99 J. Wessels, W. Beulke (see Note 43), Art. 8, Ref. 306; R. Rengier (see Note 13), Art. 19, Ref. 12; W. Gropp (see Note 45), Art. 5, Ref. 224 (the last reference cited draws a parallel with the Sword of Damocles, which could strike the person beneath it at any moment).

100 CCSCd 3-1-1-1-01.

101 C.W. Schmidt (see Note 16), p. 162.

102 See, for example, the 14.6.2016 letter of the Chancellor of Justice, no. 7-9/151298/1602606: 'Kontrollkäik SA Viljandi Haigla psühhiaatriakliiniku sundravi osakonda' (or 'Visit to the coercive treatment ward of the psychiatric clinic of SA Viljandi Haigla'), p. 2. Available, in Estonian, at http://www.oiguskantsler.ee/sites/default/files/field_document2/kontrollkaik_ sa_viljandi_haigla_psuhhiaatriakliiniku_sundravi_osakond.pdf (most recently accessed on 26.5.2017).

103 It should still be noted, however, that in non-legal (or semi-legal) literature, the institution of necessity is recommended as a basis even when the restraining takes place in the interests of the care patient. As stated above, this cannot be done in a formal sense, but, in essence, there may be situations in which the principles related to necessity can often be appealed to (see subsections 3.1 and 3.3 of this article). 
of the situation, for instance, through speaking calmly to the care patient. ${ }^{* 104}$ Naturally, this is not always a possibility, and talking may often be an inappropriate means for combating the danger. At the same time, there are situations in which it could prove fruitful. In such situations, this mechanism must to be tried instead of resorting to use of force straight away. In the case of restraining straps, the principle of sparingness requires that the person not be strapped to a bed by any more points than necessary for fending off the danger. The principle of providing as much mobility as possible and as little restraining as necessary applies. ${ }^{* 105}$ When a danger can be eliminated via simple use of a waist strap, that is what should be done; when the danger does not stop until the person is tied down by all four limbs, he or she still should not be strapped down additionally from any other parts of the body. Full strapping down (i.e., at 11 points, including the head) is permitted only in highly exceptional circumstances. ${ }^{*} 106$ At this point in the discussion, it should be noted also that restraint straps may not create a new danger, especially one that is greater than the danger being combated (results that represent lesser danger are in compliance with the principle of proportionality). Using only a waist strap creates a danger of the patient falling from the bed and dying by suffocation, which is why use of this method is seldom allowed. When it is employed nonetheless, bed rails have to be raised at all times. ${ }^{*} 107$ The principle of sparingness requires also that the straps not be too tight a hand must fit between the body of the care patient and the strap. ${ }^{* 108}$ The same principle has to be applied when medication is administered. Hence, patients may not be given more or stronger medication than what is necessary to eliminate the danger.

In addition, the interest protected must be evidently of greater importance than the interest subject to impair. Whether the criterion 'evidently of higher importance' refers to clearly more substantial weight of the interest protected or, rather, it is sufficient that the interest protected be only slightly more important than the one subject to damage may be debated, as is the case also in, for instance, German law. ${ }^{* 109}$ Since it is impossible to weigh these interests in a clearly measurable manner as might a practitioner of the natural sciences, the answer to this question is probably not so decisive, though. While all the relevant factors must be taken into consideration in the weighing process. the law has emphasised as examples the importance of the legal rights, the degree of the danger by which they are threatened, and the danger arising from the action taken against that danger (see the second sentence of $\S 29$ of the PC).

\subsection{The relationship between general and specific circumstances precluding unlawfulness}

As already stated, the circumstances characterised above and the terms for ruling out unlawfulness are general - they may apply in almost any part of life, and anyone can rely on them. Simultaneously, our legal order features a list of circumstances excluding unlawfulness that are realised only in specific situations and for a limited range of subjects. First and foremost among these circumstances excluding unlawfulness are ones that involve the behaviour of representatives of public state authority in their performance under such authority. For instance, the Code of Criminal Procedure allows various people protecting the legal order (police officers, prosecutors, and judges among them) to carry out acts that possess elements of an offence, such as detaining a suspect under §217 of the CCP (the terms of $\S 136$ of the PC with regard to necessary elements are met, and so are those in $\S 121$ of the PC if pain is inflicted on the suspect upon detention), taking someone into custody under $\$ 130$ (2) of the CCP, or punishing someone with imprisonment under $\$ 309$ of the CCP (in conjunction with $\S 45$ of the CCP) (the last two decisions listed fulfil the elements in $\$ 136$ of the PC also). Police officers are entitled to perform acts with the necessary elements of offence also under the Law Enforcement Act ${ }^{* 110}$ (LEA) (for instance, direct coercion

\footnotetext{
104 D. Fogel, T. Steinert. Aggressive und gewalttätige Patienten: Fixierung ['Aggressive and violent patients: Restraints']. - Lege artis - Das Magazin zur ärztlichen Weiterbildung 2012/2, pp. 28-33 (in German), on p. 29. Available to registered users at https://www.thieme-connect.com/products/ejournals/pdf/10.1055/s-0032-1302472.pdf (most recently accessed on 27.5.2017).

105 F. Henke (see Note 7), p. 96.

106 Ibid.

107 Ibid., pp. 95-96.

108 Ibid., p. 95.

109 R. Rengier (see Note 13), Art. 19, Ref. 43.

110 RT I, 22.3.2011, 4; RT I, 2.12.2016, 6.
} 
is regulated in Chapter 5 of the LEA), and prison officials receive such rights through the Imprisonment $\operatorname{Act}^{* 111}$ (e.g., §71).

In analysis of the relationship between general and specific circumstances excluding unlawfulness, three situations need to be kept in mind. First is the one in which the act is encompassed both by a circumstance excluding unlawfulness under some of the special laws and by a general circumstance excluding unlawfulness. For instance, if a police officer is attacked by a person with a knife and hits the attacker in self-defence by painfully striking the knife hand with a telescopic baton, the officer's liability can be excluded under $\S 121$ (1) of the PC (or, rather, its §291 (1)) both in accordance with a specific provision (§76 (1) of the LEA) and under §28 (1) of the PC. However, there are situations in which only the special provision applies and the general provision does not cover the situation. For instance, a police officer might venture onto certain premises against the will of their possessor so as to carry out surveillance activities (to plant a 'bug') or might gain access to another person's computer by removing a security safeguard or circumventing it (to install spyware). In such cases, the police officer commits a crime under §266 (2) 1) and §217 (1) of the PC: the action is not justified by any general circumstance precluding unlawfulness, inclusive of §29 of the PC, because the police officer is acting only on suspicion of a crime. No immediate danger is combated. The police officer's action can be justified, however, under $\S 126^{3}(5)$ of the CCP. It is possible also to identify a situation in which a police officer (or anyone; see §217 (4) of the CCP) catches a criminal fleeing a crime scene. While escaping, the criminal is no longer committing the unlawful attack within the meaning of $\S 28$ (1) of the PC and poses no immediate danger in the sense of §29 of the PC. This is why §217 of the CCP should be the basis. Thirdly, situations arise in which the actions of a person operating in a specific field are not covered by any specific circumstance precluding unlawfulness while a general provision is relevant. For instance, a prison guard could be attacked by a prisoner with a knife, whereupon the guard hits the prisoner in the head with a telescopic baton. With that action, the guard breaches the laws on imprisonment (which do not allow hitting people in the head with a baton) but does act in compliance with §28 (1) of the PC. ${ }^{* 12}$ Additionally, use of a firearm can be referred to in this connection. Special legislation imposes extremely strict restrictions on such actions, but use of a firearm out of necessity does often afford significantly more leeway.

These two situations are not problematic with regard to penal law. In the first example (the act permitted by dint of both a general and a specific circumstance precluding unlawfulness), it is clear that no liability arises. It should be precluded on the specific-provision basis because lex specialis derogat legi generali. The situation is clear also in the next set of cases referred to: liability is precluded by the specific provision. In the third situation, however, things are not so clear. This issue has been wrestled with for decades in Germany without reaching of consensus, in which time several theories have been developed, of which the three main ones have been highlighted in brief in the Estonian legal literature ${ }^{* 113}$ : Proponents of public-law theory find that only the special law can be applied, because, otherwise, setting more restrictive provisions in place for special subjects under special law would be rendered meaningless. Supporters of penal-law theory (which is adhered to by the German courts) argue that in a case of a general circumstance precluding unlawfulness, no accusations can be made against a person who commits the act in question as a special subject operating in a special field, either under penal law or on any other grounds (e.g., in disciplinary proceedings). A person's position as a special subject may not lead to that person losing recourse to some of the circumstances precluding unlawfulness that are applicable to him or her. The overriding perspective in this regard seems to be one that represents a compromise - from the third perspective, in the event that a general circumstance precludes unlawfulness, criminal liability is ruled out but disciplinary liability remains. ${ }^{*} 114$

111 RT I 2000, 58, 376; RT I, 1.3.2017, 4.

112 A. Soo, K. Tarros. Enesekaitsesituatsioonides vahetu sunni kasutamine vanglas. Karistusõiguslik ja haldusõiguslik analüüs ['The user of direct coercion in prisons in situations of self-defence: A criminal- and administrative-law analysis']. - Juridica 2015/10, pp. 707-719 (in Estonian), on p. 713.

113 Ibid., p. 712; J. Sootak. Kriisi lahendamise karistusõiguslikud lähtekohad Eesti õigussüsteemis ['Crisis resolution under criminal law in the Estonian justice system']. - Juridica 2007/2, pp. 305-328 (in Estonian), on p. 85.

114 For an outline of various theories, see B. Heinrich. Gelten die allgemeinen Rechtfertigungsgründe auch für sich im Dienst befindende Hoheitsträger? ['Do the grounds under general law apply also in public service?']. 2014 (in German). Available at https://www.jura.uni-tuebingen.de/professoren_und_dozenten/heinrich/materialien/arbeitsblaetter-zum-examinatoriumstrafrecht-pdf-dateien/strafrecht-allgemeiner-teil/11-rechtswidrigkeit04.pdf/view (most recently accessed on 27.5.2017). 
There seems to be no support for public-law theory in this regard is Estonia's scanty legal literature on our topic. Scholars' views seem inclined toward penal-law theory and the compromise theory. ${ }^{*} 15$ Also, the authors of this article hold that public-law theory cannot be applied here because if an action is allowed and fair for everyone under penal law, the same is necessarily true for a person operating in a specific part of life. This position does not render the special provisions meaningless per se. From the perspective of penal-law legitimisation of an action, they would not be necessary, but they remain useful for several other reasons. Firstly, the educational function of these provisions for the people operating in the relevant field could be addressed - it is likely that employees at a psychiatric hospital find the relatively casuistic $\S 14$ of the MHA (on means of restraint) more understandable than the highly abstract §28 of the PC, not to mention the institutions related to consent, permission, and presumptions of permission, which are not even included in the legislation. On the other hand, there is a related danger that people operating in specific fields may develop an erroneous belief that their behaviour is regulated by special provisions alone. For instance, employees at a psychiatric hospital may act on the invalid assumption that only $\S 14$ of the MHA should be observed when one is restraining a care patient, not understanding that this provision does not take priority over consent or permission (presumed or actual) of the patient; at the same time, they may not recognise that restraining care patients may be allowed in some situations not covered by $\$ 14$ of the MHA. Hence, the existence of such provisions may be considered legitimised by the fact that they ensure observance of certain norms more effectively than do provisions related to general circumstances precluding unlawfulness. For instance, the latter do not require that the lawfully restrained person be spoken with after the restraining or informed of being restrained or that the fact of restraining be documented; however, these are required by $\S \S 14^{3}, 14^{4}$, and $14^{2}$ of the MHA (violation of which could lead to, among other things, fines being due for the care institution ${ }^{* 16}$ ). Finally, the implications of these special provisions for penal law cannot be fully denied either. As is indicated above, they may help to furnish violation of a duty of care in cases of negligence delicts (see Subsection 2.2 of this article).

\subsection{Section 14 of the Mental Health Act}

Section 14 of the MHA allows using means of restraint for persons receiving involuntary emergency psychiatric care in some circumstances. In the meaning of the penal-law terms, this provision grants the right to deprive a care patient of liberty in the sense of $\$ 136$ of the PC. This may be done if there is an immediate danger of bodily harm to the patient or of violence toward other persons (see §14 (1) of the MHA). In order to combat that danger in cases wherein other means, such as talking, are ineffective, the care patient may be restrained by means of physical strength applied by caretakers or by auxiliary means, placed in an isolation room, or medicated accordingly. This must be done only on the basis of decisions by physicians and in line with the principle of proportionality (see $\S 14$ (1)-(4) of the MHA).

The authors of this article find reason for concluding that if there were no $\$ 14$ of the MHA, little would change with regard to penal law, because the admissibility of the means of restraint described in $\S 14$ of the MHA should be analysed on the basis of general circumstances precluding unlawfulness.

Without §14 of the MHA, a situation featuring 'an immediate danger of bodily harm' should be resolved through the institution of consent, permission, or presumed permission; another option that could be considered is reliance on the opinion of a guardian (see Subsection 3.7 of this article, just below). If any of the circumstances precluding unlawfulness obtains, liability of the caretakers would not be applicable. For instance, it would usually be possible to proceed from presumed permission and thereby exclude the liability of the caretakers restraining (under $\S 136$ of the PC) a person incapable of comprehension who is banging his or her head against the wall and protests against being restrained. However, if it could be presumed that the

115 A. Soo, K. Tarros (see Note 112), pp. 712, 713; A. Soo. Karistusõiguslik hädakaitse ja hädaseisund põhiõiguste piiramise alusena koolides ning nende suhestumine 1.jaanuaril 2016 jõustuva lastekaitseseaduse § 24 lõikega 3 ['Emergency protection and state of emergency as bases under criminal law for restriction of fundamental rights in schools and their relationship to the Child Protection Act’s §24 (3), effective from 1 Jan. 2016’]. - Juridica 2015/6, pp. 418-426 (in Estonian), on p. 421; L. Madise et al. Vangistusseadus. Kommenteeritud väljaanne ['Imprisonment Act: Commented Edition']. 2nd ed. Tallinn 2014 (in Estonian), §71, Comment 8; J. Sootak (see Note 113), pp. 84-86.

116 According to $\S 19^{1}$ of the MHA, supervision of provision of psychiatric care under said act shall be exercised by the Health Board on the grounds and pursuant to the procedure provided for in $\S 6$ of the Health Care Services Organisation Act, enabling both issuing precepts and setting penalty payments. 
person does not want to be restrained (e.g., before becoming incapable of comprehension, the person stated that the use of restraint straps should be avoided at all times), the caretakers should not use the straps on the person and should allow the patient to cause self-harm. Since a person's will prevails over other circumstances precluding unlawfulness (see Subsection 3.3, above) and not even special provisions refute that (see Subsection 3.5 of this article), the same considerations must be applied as things actually stand - i.e., with the existence of $\S 14$ of the MHA. If there is a reason to believe that a person who is unable to understand does not wish to be restrained, that person shall not be restrained in the event of a threat of self-harm under $\S 14$ of the MHA. The question of whether the judge making a decision or student solving a case in the presence of consent or permission (presumed or otherwise) should rely on this consent, permission, or presumption for preclusion of the act's unlawfulness or instead on $\S 14$ of the MHA has no relevance in practice. It would probably be more correct to take $\S 14$ of the MHA - that is, the special provision - as the basis, in which case, a reference to consent, permission, or presumption of permission is unavoidable. When caretakers restrain a care patient against his or her presumed or actual will, they are liable (in cases of culpable conduct) under $\$ 136$ (1) of the PC.

An immediate danger of bodily harm to other people within the meaning of §14 (1) of the MHA constitutes immediate unlawful attack as intended under \$28 (1) of the PC. This means that in the absence of $\S 14$ (1) of the MHA, the foundations could rest on grounds of self-defence in a situation of restraining a patient who employs violence toward another person. Since the presence of special provisions does not render general circumstances precluding unlawfulness inapplicable (see Subsection 3.5 of this article), restraining a patient who displays aggression against someone else's legal rights may be lawful also when it is not possible to rely on §14 (1) of the MHA, on the basis of §28 (1) of the PC. Let us imagine a situation in which a mentally ill patient starts laying waste to a car parked in a hospital car park and the medics hold the patient physically in place to prevent this from continuing. The medics cannot be spared conviction under $\S 136$ (1) of the PC via a reference to $\$ 14$ (1) of the MHA, because the latter provision allows for the use of means of restraint only for protection of rights associated with the human body ${ }^{* 117}$, not property. Restraint of the latter sort may, however, be protected under §28 (1) of the PC. If one follows the three-stage theory, the liability of the medics depends on the particular circumstances of the case. If it was possible to drive the car away (e.g., the medics had its door and ignition keys, since the car belonged to one of them or to his or her partner), that should have been done and any additional damage to the vehicle should have been prevented through escaping. For a scholar who does not adhere to the three-stage theory, escaping should not have been required.

The foregoing also means that it makes no difference from the perspective of penal law whether the person being restrained is in care voluntarily or instead involuntarily. While in the first instance sometimes the general circumstances precluding unlawfulness (presumed permission and self-defence chief among them) can be replaced with $\S 14$ of the MHA, in the second case the basis must always be general circumstances precluding unlawfulness (even though this does not change the outcome).

\subsection{Sections 106 and 107 of the Social Welfare Act}

Subsection 106 (1) of the SWA allows restricting the free movement of some persons who receive social services. Firstly, this may be done in the case of a person who is placed in a social-welfare institution for care without his or her consent (under §106 (1) 1) of the SWA). Secondly, this restriction is permissible in the case of a person who receives 24-hour special care services, if this is necessary for the protection of the rights and freedoms of said person and other persons (see $\$ 106$ (1) 2) of the SWA). The freedom of movement of persons belonging to these two groups may be restricted under \$106 (2) of the SWA only to the extent necessary for the purpose behind the restriction. In cases of people receiving 24-hour special care, the only option permitted for restriction of movement is placement in an isolation room (under $\$ 107$ of the SWA).

117 Although the legislator has used the bureaucratic jargon 'person', it is not possible to exert violence against a legal person (see §24 of the GPCCA). Hence, it can be deduced with certainty that the persons referred to are natural persons, people (see $\S 7$ (1) of the GPCCA). Also, it can be concluded from the wording of the provision that violence needs to be directed directly against the person (i.e., the person's body). This means that protection of the person's life, health, and freedom may be considered relevant but not, for instance, protection of proprietary rights. 
It is the opinion of the authors of this article that $\S \S 106$ and 107 of the SWA are unlike $\S 14$ of the MHA in that their terms are, in part, broader than the set of general circumstances precluding unlawfulness, thereby allowing room for more.

Let us firstly discuss restriction of the freedom of movement of people whose 24-hour special care service has not been ordered by a court ruling - i.e., is voluntary (under \$106 (1) 2) of the SWA). The situation here is largely the same as that in cases falling under $\$ 14$ of the MHA; that is, special provisions do not provide for greater authorisation than what could be concluded from the general norms - except in one respect.

When a person receiving 24-hour special care services is deprived of liberty to protect that person from him- or herself, the deprivation is lawful only when there is consent, permission (unlikely), or a presumption of permission from that person. When the person's consent, permission, or presumed permission exists and that person is placed in an isolation room, the unlawfulness of depriving him or her of liberty is precluded by $\S 106$ (1) 2), §106 (2), and §107 of the SWA. Although the first sentence of §107 (1) does not allow restriction of freedom of movement in any other way than by placement in an isolation room, it may nevertheless be lawful under penal law ${ }^{*} 118$ to deprive the care patient of liberty in some other way. For instance, it might be necessary to physically restrain a person before he or she can be placed in an isolation room (in fact, this is probably more like a rule in cases of placement into an isolation room). Such acts are not justified (at least not directly) by §106 (1) 2), §106 (2), or $\$ 107$ of the SWA but may still be lawful, for instance, on account of presumed permission from the care patient. On grounds of presumed permission, justification cannot be ruled out a priori also in cases of deprivation of liberty by such means as medication or restraining straps.

The statements above on $\S 14$ of the MHA are largely valid also when a recipient of 24-hour special care is deprived of liberty for protection of someone else's legal rights. In several types of instances, it is possible to rely on special provisions in $\S 106$ (1) 2), 106 (2), and 107 of the SWA that presume immediate danger to the life, physical integrity, or physical freedom of another person ${ }^{*}{ }^{* 19}$, but if those provisions are still too limited for the case at hand (e.g., one wherein the care patient attacks someone else's property), the institution of self-defence also might be considered.

However, §107 (6) of the SWA seems to allow more than the general circumstances precluding unlawfulness. It establishes that a person may be isolated from other persons receiving the service until the arrival of a provider of emergency medical care or the police, though for no longer than a span of three hours. This norm could be interpreted, at least in the grammatical sense, in such a way that a person may be held in an isolation room for three hours in any case, even when the immediate danger arising from said person (see $\$ 107$ (4) 1)) has passed. Therefore, the situation is different from that in cases of, for instance, detention under criminal law. With the latter measure, although the law provides the right to detain a person for 48 hours (under $\S 217$ (1) 1)), it also establishes that if the basis for the detention of a suspect ceases to exist during pre-trial proceedings, the suspect shall be released immediately (under §217 (9) of the CCP). When $\$ 107$ (6) of the SWA is genuinely understood as indicating that a person may be detained for three hours even when the immediate danger arising from the person no longer exists, the understanding still needs to be adjusted for situations in which the person is placed into an isolation room on account of a danger of self-harm. Once again, we cannot stress the importance of human autonomy enough - even if the caretakers had presumed permission of the person to place him or her in an isolation room, it is almost impossible to imagine that the presumed permission would also cover the time after the direct danger of self-harm has passed. When, in turn, there is no presumed permission, the caretakers have to release the person from the isolation room; otherwise, they as protection guarantors will be liable for depriving the care patient of liberty through omission under $\S \S 136$ (1) and 13 (1) of the PC. Therefore, a person who poses no immediate danger could be held in an isolation room only if having been placed there under the second alternative in $\$ 107$ (4) 1) of the SWA (which addresses immediate danger arising from the person to the life, physical integrity, or physical freedom of the same person). If, however, the Social Welfare Act contained a provision similar to §217 (9) of the CCP, this would not be possible. In that case, this provision would create a legal obligation within the meaning of $\S 13$ (1) of the PC to release the person held in the isolation room.

However, $\$ 106$ (1) 1) of the SWA is slightly more generous to caretakers than $\$ 106$ (1) 2). Firstly, unlike $\S 106$ (1) 2) (in conjunction with $\S 107$ of the SWA), it does not restrict the set of permitted ways of restricting liberty. Rather, it addresses any kind of deprivation of freedom of movement. Nevertheless, it offers no

118 However, implementation of administrative measures cannot be excluded from the start; see Subsection 3.5 of this article.

119 This probably is intended to refer to freedom of movement. 
additional value under penal law, since the general circumstances precluding unlawfulness would allow imposing various restrictions on freedom of movement anyway, if the other prerequisites are fulfilled (see the recent analysis of $\S 106$ (1) 2) of the SWA).

That said, the SWA's §106 (1) 1) differs from §28 (1) and §29 of the PC and also from §14 (1) of the MHA and $\$ 106$ (1) 2) of the SWA in that it is possible to rely on $\$ 106$ (1) 1) even when the danger to other people's life and health is not immediate. Subsection 28 (1) of the PC requires immediate danger in the form of unlawful attack, the PC's §29 anticipates immediate danger, §14 (1) of the MHA requires immediate danger of violence toward other persons, and §106 (1) 2) of the SWA in conjunction with the same act's $\$ 107$ (4) 1) requires direct danger to the life or physical integrity/freedom of another person, while \$106 (1) 1) of the SWA sets in place no such prerequisites and it is sufficient if the liberty is withdrawn for protection of the rights and freedoms of other persons (under §106 (2) of the SWA). The latter provision does not require immediate danger to life and health. Posing even a merely abstract threat to these legal rights is sufficient. This means that a person's liberty may be withdrawn for reason of a danger that said person may start damaging the life and health of other people. Such prediction must be based on certain specific circumstances, though. After all, from a purely theoretical point of view, every person poses a threat to the life or health of another person yet it is not 'necessary' to restrict the freedom of these people within the meaning of \$106 (2) of the SWA under these theoretical considerations. The prognosis should be based mainly on the prior history of the person. For instance, has this person (repeatedly) attacked fellow patients or at least attempted to do so? In that case, locking the person's door for a night may be a justified measure. If, however, the person only poses an abstract danger to property (e.g., having destroyed property of the institution on more than one occasion), even the liberty of a person receiving 24-hour special care services by court order may not be taken away, because the SWA's §106 (1) 1) (in conjunction with its $\$ 106$ (2)) does not provide for protection of property ( $\$ 28$ (1) and $\$ 29$ of the PC, however, cannot be considered to be grounds, because the attack and danger in this scenario are not immediate).

When the deprivation of liberty is in the person's own best interests, for such purposes as protecting the patient from him- or herself (these are probably the most commonplace grounds in practice), differentiation between immediate and non-immediate (abstract) danger is not relevant. That is because such cases demand taking the actual or presumed will of the patient as a basis anyway, with analysis of whether that will is in agreement or presumed agreement with the deprivation of liberty. In the absence of information that proves the contrary, it can probably be presumed that a person who has fallen out of bed on prior occasions, is weak, and is unable to comprehend agrees to having rails on his or her bed at night or to receiving a reasonable amount of medication so as to sleep better at night. It can often be presumed also that a person who has a history of wandering around the institution at night (falling or at least placing him- or herself at serious risk of falling) would probably consent to having his or her door locked at night.

On the other hand, the perennial conflict between safety and freedom must be taken into consideration in both cases - in protection of the legal rights of both other people and the persons themselves from abstract danger arising from said persons. Even when someone poses an abstract danger to someone else's legal rights, that person is not to be 'locked up forever'. In cases involving protection of the life and health of other people, this conclusion can be reached via the criterion of need established in §106 (2) of the SWA. For instance, it should probably be found that a person should not be locked in a room during the daytime because the danger posed by that person to other patients should be neutralised through supervision by caretakers. It can be convincingly argued that one should proceed from the principle of sparingness here as well - if actualisation of a danger can be avoided by any of several methods, the one that infringes least on the right of freedom of the person should be used. The same conclusion can be reached in cases wherein danger is posed to a person who is unable to comprehend. A person can be presumed to consent to only those restrictions on his or her liberty that are of reasonable extent, not to being constantly kept in a cage, as it were. Hence, he or she would most likely prefer the method that applies restrictions most sparingly. 


\subsection{Subsection 206 (1) of the Family Law Act}

It may seem surprising at first that a circumstance precluding unlawfulness could be dealt with by a provision set out in the Family Law Act ${ }^{*} 120$ (FLA). Yet one is to be found in the first sentence of §206 (1) of the FLA, establishing that a guardian shall protect the proprietary and personal rights and interests of the relevant ward. Accordingly, restraining a care patient could, in some cases, be justified also by consent of a guardian. This position is represented in German law too. The latter relies on Section 1902 of the German Civil Code (Bürgerliches Gesetzbuch, BGB), similar to the first sentence of §206 (1) of the FLA. ${ }^{* 121}$ However, in respect of Estonian law, the Chancellor of Justice has expressed the position that a guardian's consent shall not be relied upon in depriving a care patient of liberty. ${ }^{*}{ }^{122}$ At the same time, the Chancellor of Justice accepted that a guardian may provide consent for treatment of a ward on condition that a competent court authorised the guardian to take such decisions for the patient. ${ }^{*} 123$

Consent of a guardian may be admissible as justification for restraint when the following preconditions are met. It is probably implicit that, first of all, the person needs to have a guardian and the relevant authorisation must be valid. For the numerous people in care institutions who have no guardian, being subjected to acts that involve the necessary elements of an offence cannot be justified via §206 (1) of the FLA in any case. The most important element in connection with this provision is that the guardian must be formally competent to allow restraint. When the guardianship is in place only for protection of proprietary rights and interests, the guardian cannot provide valid consent to restrict the liberty of the ward. ${ }^{* 124}$ Hence, a caretaker wishing to rely on the consent of a guardian in a case of restraint needs to check, firstly, whether the court

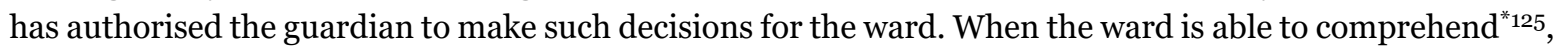
the consent of the guardian is not important; the person's own will must be considered definitive. This means that caretakers must verify whether the ward has capacity to comprehend even if there is a guardian's consent. ${ }^{*} 126$ This is probably done only in exceptional cases. In contrast, C.W. Schmidt concludes that caretakers do not need to weigh whether the consent of a guardian contradicts the presumed will of the ward - they may rely on the consent of the guardian and need not worry about any sanctions when acting in accordance with it. ${ }^{* 127}$ On exceptional cases, however, caretakers probably should not follow the guardian's instructions. For instance, this may be true in situations wherein a long-term-care patient with capacity to comprehend repeatedly articulated to caretakers a wish not to be restrained in a specific way in the future, no matter the consequences, although a guardian appointed after the patient lost the capacity to comprehend has requested the implementation of that very measure by caretakers.

Since the entry into force of the Convention on the Rights of Persons with Disabilities ${ }^{*}{ }^{* 18}$, one of the main purposes of which is gradual replacement of the decisions made by a guardian for a ward with a decision-support system ${ }^{*} 129$, consent of a guardian as ruling out unlawfulness should be taken with even greater reservations.

120 RT I 2009, 60, 395; RT I, 21.12.2016, 12.

121 C.W. Schmidt (see Note 16), p. 137.

122 See the summary of the Chancellor of Justice's 10.10.2013 inspection visit titled 'Kontrollkäik SA-sse PJV Hooldusravi' (see Note 60), p. 3. In a situation such as this, guardians and family members are placed in the same position and their consent is analysed together.

123 Ibid., p. 5.

124 Theoretically, however, there are some possible situations in which liberty is restricted for avoidance of a certain kind of proprietary damage - e.g., a ward breaks valuable items that he or she owns or a ward's act of violence toward someone else may lead to claims for compensation for damages being levied against the ward. Whether such dangers provide a guardian taking care of property with any right to allow restricting the liberty of the ward is highly debatable.

125 There is an almost unanimous position in Germany that a ward may be able to make certain decisions and be able to provide valid consent or refuse it. See C.W. Schmidt (see Note 16), p. 138 (along with subsequent references). See also the similar position expressed in Subsection 3.1 of this article. In an analogous manner, the case law of the European Court of Human Rights concludes that there should be a distinction between de jure and de facto legal capacity and that if the person is actually capable of deciding on the matters concerning him or her, that person's will should not be ignored, irrespective of the restricted legal capacity. See, for instance, EIKo 22.01.2013, Mihailovs vs. Latvia, para. 134.

126 C.W. Schmidt (see Note 16), p. 138.

127 Ibid.

128 RT II, 4.4.2012, 6.

129 General Comment 1 (2014), CRPD/C/GC/1, paragraphs 3 and 40-42, of the UN Committee on the Rights of Persons with Disabilities. Available at https://documents-dds-ny.un.org/doc/UNDOC/GEN/G14/031/20/PDF/G1403120.pdf?OpenElement (most recently accessed on 26.5.2017). 


\subsection{Court permission as a justification for restraint}

The legislation in force in Estonia does not allow implementation of means of restraint that is based on a judicial decision. In addressing this, one must note firstly that automatic permissibility of restraining cannot be derived from case law on placing people in closed institutions (e.g., §105 of the SWA); see Subsection 2.1 of this article. It is true that an explanatory memorandum on a certain Estonian draft act of law states that, since the court places a person in 24-hour special care without his or her consent, it also accepts that restrictions to the right of freedom may be applied to this person. ${ }^{*}{ }^{*}{ }^{30}$ However, it has been added that, irrespective of court orders, a person's freedom of movement should be restricted as little as possible relative to that person's dangerousness to self and others. Therefore, not even the authors of the draft act in question have found that an order for placement in a closed institution is a 'blank cheque' enabling deprivation of the care patient's liberty in an arbitrary situation. Deprivation of liberty (and other restraining) presumes a circumstance precluding unlawfulness as described above in this article.

Secondly, it may be possible for the court to allow the person to be restrained in connection with the placement in the closed institution - e.g., by adding to the resolution of the order that the caretakers have a right to restrict the patient's freedom and restrain him or her. To the best of the authors' knowledge, however, courts generally do not grant such authorisations to caretakers in their orders. If, however, it is done, such an order should not be interpreted as conferring on caretakers the right to start restricting their patient's rights as they wish. The principles laid out above should be taken as a basis (i.e., those on circumstances precluding unlawfulness). Hence, it is completely justified that courts provide no general right of restraining in their placement orders.

De lege ferenda it is fitting to refer to the situation related to court permission in Germany. Subsection 1906 (4) of the BGB establishes that when the freedom of a resident of a care institution who is under guardianship needs to be restricted by mechanical or medical means or in some other way for a longer time or regularly, there needs to be a court's permission for this. This permission must be obtained from the court before implementation of the measure or, if direct danger dictates that its implementation cannot be delayed, immediately after the measure is applied. The relevant provision of law entered into force in 1992 when the German legislator decided to formalise case law that had been applied for years. Namely, for some years before the entry into force of Subsection 1906 (4) of the BGB, German courts had been requesting that representatives of care institutions be able to request court permission to hold a patient in place with restraining straps, use bed rails, etc. ${ }^{*}{ }^{11} \mathrm{It}$ is important to note that the court in these cases does not issue a blank cheque but analyses the particular situation, taking into consideration the specific person involved, the means of restraint applied, and other relevant matters. The definition of the provision's language 'longer period of time' is disputable - some requests are for as much as a week, while others indicate a need for three days and still others just 48 hours. ${ }^{*} 132$ However, the prevailing understanding seems to be that deprivation of liberty for 24 hours or more requires a court's permission. ${ }^{*}{ }^{133}$ Deprivation of liberty is considered to be 'regular' when it takes place at the same time or in consequence of a recurrent factor (e.g., closing off the exit routes each night). In cases of regular physical restraint, the duration of the deprivation of liberty is of no consequence; when regular, even short-term restriction necessitates permission. ${ }^{*} 34$ In making the decision on granting permission, the court needs to consider provisions regulating guardianship $^{* 135}$, turning the most attention to the principle established in Subsection 1901 (2) of the BGB whereby guardianship is in the interests of the ward.

130 Sotsiaalhoolekande seaduse, puuetega inimeste sotsiaaltoetuste seaduse ja nendega seonduvate seaduste muutmise seaduse seletuskiri, 370 SE (the explanatory memorandum on the Social Welfare Act, the Social Benefits for Disabled Persons Act, and the law related to Associated Acts), p. 65. Available, in Estonian, at https://www.riigikogu.ee/tegevus/eelnoud/ eelnou/13f8b46d-2f09-9470-40a3-31e3c10bf788/Sotsiaalhoolekande\%20seaduse,\%20puuetega\%20inimeste\%20sotsiaaltoetuste\%20seaduse\%20ja\%20nendega\%20seonduvate\%20seaduste\%20muutmise\%20seadus (most recently accessed on 26.5.2017).

131 C.W. Schmidt (see Note 16), pp. 128-129.

132 See C.W. Schmidt's overview: ibid., p. 131.

133 F. Henke (see Note 7), pp. 25, 42, 159; C.W. Schmidt (see Note 16), p. 120; C. Fuchs (see Note 24 ), p. 10.

134 H.G. Bamberger, H. Roth (eds). Bürgerliches Gesetzbuch. Beck'scher Online-Kommentar ['The Civil Code: Beck's Online Commentary’]. 42nd ed. Munich, Germany, 2017 (in German), §1906, Comment 32 (G. Müller).

135 Ibid., Art. 1906, Comment 26 (G. Müller). 
In the assessment of the authors of this article, it would be reasonable to analyse whether a provision similar to Subsection 1904 (6) of the BGB should be added to Estonian law. It is possible that were such a provision to exist, it would prevent arbitrary restrictions to the freedoms of care patients. Also, it would provide certainty to the caretakers that the restraining they are applying is lawful - they would be able to rely on a clear judicial decision. In addition, legal circles in Estonia should consider whether a court's permission should be tied in with guardianship (as is done in Germany). It has to be acknowledged that such regulation would be quite resource-intensive, mainly in terms of the workload for courts. However, concerns surrounding resource-intensiveness should not prevent at least bringing these topics into discussion.

\subsection{Error related to circumstances that preclude unlawfulness, under the Penal Code’s §31 (1)}

The first sentence of the Penal Code’s $\$ 31$ (1) states that an intentional act is not unlawful if, at the time of commission of the act, the person erroneously assumes the existence of circumstances that would preclude the unlawfulness of the act. The second sentence of the same section of law establishes the conditions under which a person is liable for an offence committed out of negligence.

Therefore, according to Estonian law, an act involving the necessary elements of an offence is not necessarily unlawful even when its execution is not prevented for reason of any substantial circumstance precluding unlawfulness. This is due to the fact that, in a formal sense, an error pertaining to circumstance that preclude unlawfulness may make an action lawful. ${ }^{*}{ }^{6}$ That means that if a caretaker has deprived the care patient of liberty within the meaning of $\$ 136$ (1) of the PC because the care patient's action constituted an immediate unlawful attack on the health of another person - i.e., the foundation that should have existed for justifying restraint in line with whichever of $\S 14$ (1) of the CCP, §106 (1) 1) or 106 (1) 2) of the SWA, or $\S 28$ (1) of the PC is applicable to the relevant situation - the caretaker's liability is not established under the first sentence of $\$ 31$ (1) of the PC. Neither is liability established under the second sentence of $\$ 31$ (1) of the PC, because negligent deprivation of liberty is not criminalised. The same is true when a caretaker wrongfully proceeds on the basis that the action is justified by presumed permission of a patient with no capacity to comprehend. For instance, a doctor may administer an injection of a calming medicine to a care patient who has no ability to comprehend and who is harming him- or herself but who when still having comprehension capacity had expressed a wish not to be injected with medicines in the future.

It should be noted that in cases falling under the first sentence of $\$ 31$ (1) of the PC, the offender's actual understanding of the situation is the relevant element. Whether the error could have been avoided in a case of more diligent conduct is of no importance. Thereby, Estonian legislators have opted for regulation that is friendly toward resolving various errors of circumstances at the level of unlawfulness. This stands in contrast to $\$ 39$ (1) of the PC, according to which a person is deemed to have acted without guilt if he or she is incapable of understanding the unlawfulness of his or her act and cannot avoid the error. ${ }^{*} 37$

\section{Conclusions}

In summary, it can be concluded that performance of the various compositions of the special part of the Estonian Penal Code is relatively easy in respect of implementing the means of restraint employed at care institutions. This is mainly in the context of $\$ 136$ of the PC, which presumes depriving a person of liberty in almost any way - tying the person up, locking him or her in a room, administering sedatives, etc. In addition to penal-law provisions addressing deprivation of liberty, there are relevant provisions under criminal

136 From a legal dogmatics perspective, this situation is problematic. How could it be said that a certain unlawful action is not objectively (!) unlawful for reason of the person who committed the act having deliberately miscalculated the existence of some circumstances? In the case of Germany, for example, the situation is different - such an error would not make the act legal, although it could bring about non-liability. See R. Rengier (see Note 13), Art. 30, refs 7-9.

137 CCSCd 3-1-1-108-13, para. 14. It should be added for comparison that in Germany, for instance, such situations are not regulated by the law and huge disputes arise on how to resolve cases of this nature. See, for example, J. Wessels, W. Beulke (see Note 43), §11, refs 467-480. Subsection 31 (1) of the PC is a partially failed attempt by the Estonian legislator to add the predominant opinion among the nation's people to the Penal Code, similarly to the attempt at writing an option on this into the German penal code. 
law - for instance, found in the PC's $\S \S 121,123$, and 124. Furthermore, holding a caretaker liable for causing death due to negligence is not excluded (see $\$ 117$ of the PC). The general and specific circumstances precluding unlawfulness that have been analysed in this article may, in some cases, exclude the liability of the person doing the restraining at least under penal law; however, mainly in the interests of care patients, legal experts should examine whether Estonian law should take the same road as its German counterpart giving courts the jurisdiction to decide on whether restraining measures should be applied in the specific case at hand, along with what kinds of measures may be suitable. It should be noted that in several of the situations presented in the article, neither general nor specific circumstances precluding legal rights do not exclude the liability of the offender. Therefore, restraining that is done under court permission would provide a sense of safety both for caretakers and for the care patients. 